https://helda.helsinki.fi

\title{
Kielikontaktien tutkimus
}

\section{Wahlström, Max}

Suomalaisen Kirjallisuuden Seura

2020

Wahlström , M \& Lindstedt , J S 2020 , Kielikontaktien tutkimus . julkaisussa M Luodonpää-Manni , M Hamunen , R Konstenius , M Miestamo , U Nikanne \& K Sinnemäki (toim), Kielentutkimuksen menetelmiä I-IV . Suomalaisen Kirjallisuuden Seuran toimituksia, Nro 1457 , Suomalaisen Kirjallisuuden Seura , Helsinki, Sivut 557-595 . https://doi.org/10.21435/skst.1457

http://hdl.handle.net/10138/335317

https://doi.org/10.21435/skst.1457

cc_by_nc_nd

publishedVersion

Downloaded from Helda, University of Helsinki institutional repository.

This is an electronic reprint of the original article.

This reprint may differ from the original in pagination and typographic detail.

Please cite the original version. 


\title{
Luku 12 Kielikontaktien tutkimus
}

\author{
Max Wahlström \\ (1) https://orcid.org/0000-0002-9585-5217 \\ Jouko Lindstedt \\ (D) https://orcid.org/0000-0001-9021-7622
}

\begin{abstract}
Mikä?

\section{Katso myös:}

Luku 14 Kielitypologian menetelmät

Luku 15 Historiallinen ja vertaileva kielentutkimus

Luku 16 Antropologinen lingvistiikka

Luku 21 Sosiolingvistiikka
\end{abstract}

Kielikontaktien tutkimus tarkastelee kahden tai useamman kielimuodon kohtaamiseen liittyviä ilmiöitä. Usein tutkimuskohteena on kielikontaktin aikaansaama kielenmuutos, mutta huomio voi olla myös esimerkiksi monikielisiin tilanteisiin liittyvissä ilmiöissä ja käytänteissä. Kielikontakti voi vaikuttaa kaikkiin kielen tasoihin, ja siksi tutkimuksessa käytetyt menetelmät ovat usein samoja kuin muilla kielitieteen aloilla. Kontakti-ilmiöiden ymmärtäminen ja kontaktilähtöisen kielenmuutoksen osoittaminen vaativat tyypillisesti useiden eri menetelmien soveltamista. 


\section{Johdanto}

Kielikontakti tarkoittaa laajimmillaan mitä tahansa tilannetta, jossa on tavalla tai toisella läsnä enemmän kuin yksi kielimuoto, olivatpa sitten kyseessä puhutut, viitotut tai kirjoitetut kielet. Useimmiten kielikontaktien tutkimuksen kiinnostuksen kohteena ovat ainakin jossain määrin toistuvat monikieliset tilanteet ja tällaisten tilanteiden kielelliset seuraukset eli kontaktilähtöinen kielen muutos.

Kielikontaktin laajimman määritelmän kannalta on vaikea sanoa, mihin kielentutkimuksen alaan kielikontaktit eivät millään tavalla liittyisi. Vaikka ajateltaisiin yksikielistä puhujaa, joka on tekemisissä vain samaa kieltä puhuvien ihmisten kanssa, hän altistuu mahdollisesti myös toisille murteille. Hän käyttää todennäköisesti myös lainasanoja, vaikka kyseinen yhteisö ei kyseisellä hetkellä olisikaan tekemisissä muiden kielten puhujien kanssa. Lisäksi puhujan kieli muistuttaa todennäköisesti rakenteeltaan muita samalla alueella puhuttuja kieliä, vaikka ne eivät olisikaan sille sukua. Lainasanasto ja tietyille maantieteellisille alueille tyypilliset, kielikuntarajat ylittävät rakennepiirteet kertovat historiallisista kontakteista. Turvallisinta onkin olettaa, että jokainen kieli on historiansa aikana ollut alttiina kielikontakteille ja että kielen kulloinenkin asu on aina jossain määrin kontaktien muovaama.

Kielikontaktien ja niiden seurausten esiintyminen lähes kaikkialla ei merkitse kuitenkaan sitä, että niiden rooli olisi helppo osoittaa esimerkiksi kielen muutosta selitettäessä. Kontaktilähtöisiä selityksiä on lisäksi vieroksuttu aiemmassa historiallisessa kielentutkimuksessa: kontaktiselitys on kelvannut usein vain siinä tapauksessa, että muutosta ei ole voitu selittää kielensisäisillä tekijöillä. Synkroniselle kielentutkimukselle voi lisäksi olla melko yhdentekevää jonkin piirteen tai sanan alkuperä, eritoten mikäli ilmiön kontaktilähtöisyys ei ole puhujien yleisessä tiedossa. Tosin mikäli jonkin piirteen alkuperä kuitenkin on tiedossa esimerkiksi siitä syystä, että puhujat tunnistavat sen selkeästi lainatuksi jostakin tietystä kielestä, arkiajattelussa tällaiseen piirteeseen voi liittyä esimerkiksi kielteisiä asenteita. Myös kielen normittamiseen on lähes 
aina liittynyt puristisia pyrkimyksiä, joiden tarkoitus on nimenomaisesti puhdistaa vieraaksi katsottu aines.

Kielikontakteja tutkitaan monella kielitieteen alalla. Karkeasti lähestymistapoja voi rajata sen mukaan, keskittyykö tutkimus synkronisesti havainnoitaviin ilmiöihin vai aiemmin tapahtuneiden kontaktien jättämiin jälkiin kielissä. Lisäksi kielikontaktien roolin arviointi on useimmiten olennainen osa niin historiallista kielentutkimusta kuin kielitypologiaa (ks. Historiallinen ja vertaileva kielentutkimus; Kielitypologian menetelmät tässä kirjassa). Lähestymistapojen moninaisuudesta johtuen kielikontaktien tutkimuksessa käytettyjä metodeja onkin lukuisia, ja vain osa niistä on käytössä yksinomaan kontaktien tutkimuksen piirissä. Tämä käy ilmi esimerkiksi merkittävimmän laaja-alaisen kielikontaktien tutkimuksen aikakausjulkaisun Journal of Language Contact artikkelikirjosta.

Seuraavassa luvussa esitellään kielikontaktien tutkimuksen historiaa. Kielikontaktitutkimuksen monialaisuuden vuoksi menetelmiä ja niiden valintaa lähestytään tutkittavien ilmiöiden ja alan teoreettisten peruskysymysten kautta. Kolmannessa luvussa käsitellään kielikontakteja kielenmuutoksen selittäjänä (3.I.), kontaktitilanteiden tutkimusta (3.2.), kontaktin historian arviointia sen tuloksen kautta (3.3.), areaalilingvistiikkaa eli kontaktialueiden tutkimusta (3.4.), kontaktin synnyttämiä uusia kielimuotoja (3.5.) ja kontaktien tutkimuksen sekä typologian suhdetta (3.6.). Lopuksi esitetään kootusti, mitä menetelmällisiä valmiuksia kielikontaktien tutkijalta vaaditaan.

\section{Kielikontaktien tutkimuksen historia ja sen asema historiallisessa kielentutkimuksessa}

Kielikontaktien tutkimuksen historia ulottuu paljon kauemmaksi menneisyyteen kuin itse käsite. Esimerkiksi sanaston lainautuminen tunnettiin ilmiönä jo antiikissa, vaikka etymologinen tutkimus ymmärrettiin pitkään varsin toisella tapaa kuin nykyään: etymologiassa oli kyse sanojen merkityksen ja alkuperän selittämisestä usein varsin 
vaikutelmanomaisesti, ja vasta I80o-luvulla lainasanoista tuli systemaattisen tutkimuksen kohde. Lainasanatutkimusta voidaankin pitää ensimmäiseksi vakiintuneena kielikontaktien tutkimuksen suuntauksena.

Lainasanatutkimuksen kehitys on tiiviisti yhteydessä nuorgrammaattisen historiallis-vertailevan kielitieteen syntyyn ı8oo-luvulla. Säännöllisten äännevastaavuuksien löytyminen sukukielten välillä mahdollisti niin kielten sukulaissuhteiden toteamisen kuin kantakielten rekonstruktion. Samankaltainen säännöllinen vastaavuus äänteiden välillä havaittiin myös lainasanastossa: tietystä kielestä tiettyyn aikaan lainautuneiden sanojen äänteistö korvataan lainansaajakielessä aina tietyillä äänteillä. Toisaalta lainasanat on pystyttävä erottamaan niistä sanoista, jotka osoittavat kielisukulaisuutta. Lainasanatutkimus ja historiallinen kielentutkimus muotoutuivat pian symbioottisiksi: niin äänteistön rekonstruktion kuin kielen muutoksen suhteellisen ja absoluuttisen ajoituksen osalta lainasanojen tuntemuksella on keskeinen merkitys (ks. Historiallinen ja vertaileva kielentutkimus tk.).

Historiallis-vertailevan kielentutkimuksen saavutukset, kuten uusien kielikuntien löytyminen ja kielten välisten suhteiden mallintaminen sukupuuna, toivat mukanaan myös havaintoja, joiden selittämiseen äännevastaavuuksiin perustuva metodiikka ei pystynyt. Eräs näistä havainnoista liittyi kolonialismin synnyttämiin kielitilanteisiin. Joidenkin, usein afrikkalaisten tai afrikkalaistaustaisten yhteisöjen kieleksi oli muodostunut sanastoltaan eurooppalaisten kolonisoijien kieliin pohjautuva mutta kieliopiltaan uudelleenjärjestynyt kreoli, joka oli usein syntynyt usean kielen kontaktitilanteessa. I8oo-luvun loppupuolelle asti kielitieteilijöiden suhtautuminen kreoleihin heijasteli tuon ajan rasistista ja etnosentristä ihmiskäsitystä: kreolit erosivat leksifioijakielistään esimerkiksi vähäisemmällä sanataivutuksellaan, mikä tulkittiin muun muassa kreolien puhujien älylliseksi kykenemättömyydeksi omaksua kehittyneempinä pidettyjen eurooppalaiskielten kielioppia (ks. myös luku 3.6.).

Kontaktikieliksi kutsuttujen kielimuotojen, kuten juuri kreolien mutta myös pidginien ja sekakielten (sa. Mischsprache, engl. mixed language), tutkimuksen uranuurtajana voidaan pitää saksalaista Hugo Schuchardtia (I842-I927; ks. Meijer \& Muysken I977; kontaktikielistä ks. luku 3.5.). Schuchardt tunnetaan myös nuorgrammaatikkojen 
sukupuumallille vaihtoehtoisen aaltomallin kehittäjänä. Vaikka aaltomalli kunnianhimoisimmassa muodossaan unohtuikin, Schuchardtin nuorgrammaatikkoihin kohdistamaan kritiikkiin liittyi elementtejä, jotka I900-luvun lopulla saivat laajan hyväksynnän. Parhaiten näistä tunnetaan Schuchardtin ajalleen vastavirtainen näkemys, että kaikki kielet ovat enemmän tai vähemmän "sekakieliä", toisin sanoen on oletettava, että jokainen kieli on ollut jonakin aikana alttiina kielikontaktille (ks. esim. Nicolaï 2014, 228-232).

Vuosikymmentä myöhemmin puolalaissyntyinen Jan Baudouin de Courtenay (I845-I929) pohti, Schuchardtin hengessä, kaikkien kielten kontaktiluonnetta (Boduen-de-Kurtenè I9OI). Hänen tarkastelukulmansa ei liittynyt kuitenkaan historialtaan läpinäkyviin kontaktikieliin, kuten kreoleihin, vaan ilmiöihin, joita nykyään kutsutaan areaalilingvistisiksi. Kielitieteellisen kiinnostuksen kohdistuessa yhä useampaan kieleen ja kielikuntaan havaittiin, että joillakin alueilla puhutut kielet muistuttivat toisiaan merkittävästi, vaikka ne eivät olleet lähisukukieliä tai sukua ollenkaan. De Courtenayn yhtenä kiinnostuksen kohteena olleiden Balkanin kielten (kreikan, albanian, eteläslaavilaisten ja Balkanin romaanisten kielten) osalta tällaisia havaintoja esitettiin jo I80o-luvun alussa (Kopitar I829). Pohjois-Amerikassa vastaavia havaintoja kielipiirteiden leviämisestä teki Franz Boas (I858-I942; ks. esim. I9II, 47-53) mantereen luoteisosan alkuperäiskielissä.

Tällaisten toisiaan muistuttavien naapurikielten ryhmien nimitykseksi vakiintui kieliliitto (sa. Sprachbund < ven. jazykovoj sojuz) Nikolai Trubetzkoyn (I890-I938; Trubetzkoy I928, I8) ensimmäisessä kansainvälisessä lingvistikongressissa esittelemän ehdotuksen myötä. Trubetzkoyn ehdotuksessa kieliliitto ja kielikunta (sa. Sprachfamilie) olivat kieliryhmän (sa. Sprachgruppe) alakäsitteitä. Siinä missä kielikunta määrittyy kielisukulaisuuden kautta, tällaista yhteyttä ei kieliliiton kielillä ole. Määritelmässä kieliliiton kielet muistuttavat toisiaan suuressa määrin syntaksiltaan ja morfologiselta rakenteeltaan. Niissä on merkittävä määrä yhteisiä kulttuurisanoja ja mahdollisesti myös pinnallisia äänteellisiä samankaltaisuuksia, erona kielikunnissa esiintyviin yhteiseen perussanastoon ja säännöllisiin äännevastaavuuksiin. Usein on esitetty näkemyksiä, joiden mukaan Trubetzkoyn määritelmän taustalla olisi 
ollut lähinnä Balkan parhaiten tuolloin tunnettuna kieliliittona. Kuitenkin esitellessään käsitteen ensimmäistä kertaa Trubetzkoy (1923) mainitsee Balkanin ainoastaan alaviitteessä keskittyen hahmottelemiinsa uralilais-altailaiseen ja Välimeren kieliliittoihin, joita nykyään pidettäisiin kokonsa vuoksi pikemmin makroalueina.

\section{Eurooppa kontaktialueena}

Euroopassa puhuttavat indoeurooppalaiset kielet olivat pitkään se normi, johon muun maailman "eksoottisia" kieliä eksplisiittisesti tai implisiittisesti verrattiin. Tilanne oli nurinkurinen, sillä Euroopan kielet edustavat vain noin 1-2 prosenttia maailman kielistä - kahden prosentin suuruusluokkaan pääsemiseksi on otettava mukaan myös Kaukasian kielet. Kielitypologisen tutkimuksen myötä on noussut esiin se käsitys, että Euroopan kielet ovatkin varsin epätavallisia koko maailman mittakaavassa ja että Eurooppa, varsinkin Länsi- ja Keski-Eurooppa, on tiivis kielellinen alue, jossa kielet ovat lainanneet toisiltaan piirteitä kontaktien kautta. Jotkut tutkijat puhuvat jopa Euroopan kieliliitosta samaan tapaan kuin Balkanin kieliliitosta.

Euroopan Tiedesäätiö rahoitti vuosina 1990-1994 laajaa EUROTYPprojektia. Sen tulokset julkaistiin kahdeksassa paksussa niteessä, joissa Euroopan kieliä on kuvattu typologisesti monesta eri näkökulmasta. EUROTYP-projektiin keskeisesti osallistunut Martin Haspelmath esitti teesin Euroopasta kielellisenä alueena tai jopa kieliliittona, jolle hän antoi nimen SAE eli Standard Average European (Haspelmath 1998; 2001; SAE oli alun perin Benjamin Lee Whorfin 1930-luvulla kehittämä termi, jolla hän kuvasi eurooppalaisten kielten välittämän käsiterakenteen samankaltaisuutta, ks. esim. Whorf 2012, 178). Euroopan kielten yhteisiä piirteitä ovat käsitelleet myös Heine ja Kuteva (2006).

Haspelmathin esittämiä piirteitä ovat esimerkiksi määräinen ja epämääräinen artikkeli, relatiivipronominilla muodostettava relatiivilause, 'omistaa'-apuverbiä käyttävä perfektitempus ja partisiippien avulla muodostettava passiivilause. Millä metodeilla tällaisten piirteiden leviämistä 
kielikontaktien kautta voidaan tarkastella ja perustella? Tässä voidaan erottaa kolme vaihetta:

1. Ensin on osoitettava, että näitten piirteitten esiintyminen alueen kielissä on suurempi kuin pelkän sattuman kautta voitaisiin odottaa. Tähän on nykyään hyvänä apuna verkossa konsultoitavissa oleva The World Atlas of Language Structures (WALS): vaikka siitä aina väliin paljastuu virheitä yksittäisten kielten kuvauksissa ja isompien kielten osalta kuvaukset perustuvat kirjakieliin, se antaa kuitenkin hyvän kuvan siitä, mikä on yleistä, mikä harvinaista ja millainen maantieteellinen jakauma eri piirteillä on. Euroopan kielistä löytyy tosiaan monia yleisiä rakennepiirteitä, jotka erottavat ne kartalla selvästi naapurialueista (Keski-Aasiasta, Lähi-idästä ja Pohjois-Afrikasta) tai jopa koko maailmasta, joten ei ole järkevää olettaa, että jokainen Euroopan kieli olisi kehittänyt ne toisista riippumatta.

2. Sen jälkeen on osoitettava, etteivät yhteiset piirteet ole kielisukulaisuuden aiheuttamia. Tämähän voisi hyvinkin olla mahdollista, koska suurin osa Euroopan kielistä kuuluu indoeurooppalaiseen kielikuntaan ja Haspelmathin piirteet ovat keskittyneet niihin, vieläpä nimenomaan romaanisiin ja germaanisiin kieliin; slaavilaisissa kielissä ja esimerkiksi uralilaisissa kielissä unkarissa ja suomessa piirteitä on vähemmän. Kielihistoriallinen tieto osoittaa kuitenkin, ettei näitä piirteitä ollut indoeurooppalaisessa kantakielessä (tai missään Euroopan indoeurooppalaisten kielten myöhemmässä yhteisessä kantakielessä) ja että useat niistä kehittyivät ja levisivät vasta ajanlaskumme ensimmäisellä vuosituhannella, kun indoeurooppalaiset kielet olivat jo lähteneet kukin omalle kehitystielleen. SAE-piirteiden keskittyminen Eurooppaan ei siis johdu kielisukulaisuudesta. (Sukukieltenkin yhteinen piirre voi siis olla kontaktilähtöinen, jos sitä ei esiintynyt niiden yhteisessä kantakielessä.)

3. Vaiheet 1-2 riittävät osoittamaan piirteet kontaktilähtöisiksi, mutta hypoteesi saa vielä lisävahvistusta, jos piirteitten lainautumisen mekanismia ja sen sosiaalista kontekstia voidaan kuvata tarkemmin. Haspelmath esittää useitten (vaikkei kaikkien) SAE-piirteiden levinneen kielestä toiseen vanhan ajan ja keskiajan taitteessa kansain- 
vaellusaikana, jolloin Euroopan väestölliset ja valtiolliset olosuhteet muuttuivat radikaalisti. Euroopan kontaktialueen ydintä eli SAE-piirteiden keskittymää Länsi- ja Keski-Euroopassa kutsutaankin joskus "Kaarle Suuren kieliliitoksi" (engl. Charlemagne sprachbund, van der Auwera 1998, 824).

Samanaikaisesti kun havaintoja kontakti-ilmiöistä alettiin esitellä, nousi esiin kysymys kontaktilähtöisen kielenmuutoksen mekanismeista. Italialainen Graziadio Isaia Ascoli (I829-I907) kehitteli I80o-luvun loppupuoliskolla niin kutsutun substraattiteorian, jonka mukaan murteiden eriytymisen taustalla on usein kielenvaihto (ks. esim. Pellegrini I980, 45). Substraatti on osa Ascolin luomaa käsitteistöä kielikontaktin sosiolingvistisille asetelmille: Substraatti on syrjäytynyt kieli, jonka vaikutus on nähtävissä sen syrjäyttäneessä kielessä, ja tyypillisesti substraatti havaitaan äänteistössä ja paikannimistössä. Adstraatilla puolestaan tarkoitetaan kieltä, joka on vaikuttanut toiseen kieleen kummankaan syrjäytymättä. Usein oletetaan myös, että adstraattisuhteessa olevat kielet ovat prestiisiltään eli arvostukseltaan samankaltaista. Superstraatti on sosiaalisesti hallitseva kieli, joka vaikuttaa sosiaalisesti alempaan kieleen; jotkut käyttävät termiä tilanteessa, jossa superstraatti syrjäyttää substraatin, jotkut taas tilanteessa, jossa superstraatti itse lopulta katoaa toisen kielen tieltä sosiaalisesti korkeammasta asemastaan huolimatta. Superstraattina voi toimia esimerkiksi lingua franca, eri kielten puhujien keskinäisessä kommunikaatiossa käyttämä yleiskieli kuten englanti nykyään suuressa osassa maailmaa. Toinen italialainen kielitieteilijä, Matteo Bártoli (1873-1946), puolestaan kehitti malleja kielellisten innovaatioiden leviämisestä maantieteellisesti ja prestiisin merkityksestä näiden omaksumisessa (Hall ı946).

Kielikontaktien mekanismien tutkimus monipuolistui I9०o-luvun loppua kohti. Italialaisten kollegoidensa tavoin nykyaikaisen kielitieteen yksi uranuurtaja, Leonard Bloomfield (I887-I949), pyrki tarkastelemaan kontaktilähtöisen kielenmuutoksen vuorovaikutuksellisia ulottuvuuksia niin eri kielten kuin kielen varieteettien välillä (ks. esim. Bloomfield 
I933, 445-495). Sosiolingvistiikan nousu toi mukanaan tarkempia malleja kieliyhteisöiden tarkasteluun, ja kielikontaktitutkimuksen klassikossa, Uriel Weinreichin (1926-1967) teoksessa Languages in Contact (I970 [I953]), keskeisellä sijalla ovat havainnot toisen kielen oppimisesta ja monikielisyydestä. I900-luvun lopulle tultaessa asemansa olivat vakiinnuttaneet myös sellaiset lähtökohdiltaan synkronista kielikontaktien tutkimusta edustavat alat kuin koodinvaihdon tutkimus ja sosiolingvistinen monikielisyyden tutkimus (ks. luku 3.2.).

\section{Miten kielikontakteja tutkitaan}

Kielikontaktien tutkimuksessa käytetyt menetelmät riippuvat siitä, millaisia kontakti-ilmiöitä havainnoidaan ja mitä kontaktilähtöisen muutoksen osa-aluetta on tarpeen kuvata ja selittää. Tämä luku esittelee kontaktitutkimuksen metodologiaa ilmiöiden ja niiden selittämisen lähtökohdista.

\subsection{Millaiset muutokset voivat olla kontaktilähtöisiä}

Kielitieteessä oli pitkään vallalla käsitys, jonka mukaan kieli voi omaksua toisesta vain sellaisia piirteitä, jotka jollakin tapaa sopivat sen rakenteeseen ja omiin kehitystendensseihin; tällaisia käsityksiä ovat esittäneet esimerkiksi Antoine Meillet, Edward Sapir ja Roman Jakobson (Thomason 200I, 63). Näyttää kuitenkin siltä, että mille tahansa tällaiselle strukturaaliselle rajoitukselle löytyy vastaesimerkkejä, jos kontaktitilanne on sosiolingvistisesti tarpeeksi kontaktia suosiva. Tämän osoittivat erityisesti Sarah Thomason ja Terrence Kaufman (1988, I3-34) paljon siteeratussa kielikontakteja käsittelevässä monografiassaan (vrt. myös Thomason 2001, 63-66).

Tästä huolimatta on totta, että rakenteeltaan samankaltaiset kielet lainaavat toisiltaan piirteitä kielen eri tasoilla helpommin kuin 
typologisesti kovin erilaiset. Sen lisäksi kielen tietyillä osa-alueilla kontaktivaikutus on todennäköisempää kuin toisilla. Kontaktivaikutukselle herkintä on sanasto mutta myös fonologia. Niinpä esimerkiksi suomi on lainannut runsaasti sanoja ruotsista. Suomenruotsi on puolestaan lainannut suomesta enemmän sanoja kuin ruotsinruotsalaiset murteet, ja se on myös lähestynyt suomea ääntämiseltään - siinä ei esimerkiksi esiinny juurikaan tooniaksenttia eikä klusiilien aspiraatiota (Kuronen \& Leinonen 200I). Seuraavaksi herkimmin kieli ottaa vaikutteita toisista kielistä syntaksissa. Esimerkki aivan tuoreesta syntaktisesta lainavaikutuksesta englannista suomeen on konjunktion koska käyttö ilman predikaattiverbiä, kausaalisen preposition tapaan, esim. en tehnyt läksyjä koska harkat. Vastaava englannin because-sanan käyttö valittiin American Dialect Societyn "vuoden sanaksi" 20I3 (Steinmetz 20I4), joten piirre on lainattu suomeen aivan tuoreeltaan.

Vaikeammin tutkittavia mutta ilmeisesti varsin helposti tapahtuvia ovat kontaktilähtöiset muutokset semantiikassa, varsinkin yksittäisten sanojen merkityksessä, erityisesti jos puhujat pitävät kahden eri kielen sanoja samoina. Niinpä suomen kontrolli on perinteisen merkityksensä 'valvonta, tarkistus' lisäksi saanut englannin vaikutuksesta myös merkityksen 'hallinta, ohjaus' (menetin pyörän kontrollin alamäessä), ja tieteen ja tekniikan kehityksen asemesta puhumme yhä useammin tieteen ja teknologian kehityksestä, koska englannin technique 'taituruus; menetelmä' on merkitykseltään suppeampi kuin suomen tekniikka.

Vaikeimmin lainautuu sidonnainen morfologia eli erilaiset affiksit. Johtimet lainautuvat kuitenkin helpommin kuin kieliopilliset affiksit; esimerkiksi ruotsista suomeen lainatun -(U)ri-johtimen (nahkuri, kankuri, suursyömäri) alkuperä on viime kädessä latinassa (-ārius), josta se on levinnyt moniin eurooppalaisiin kieliin. Taivutusmorfologiassa on tavallisempaa, että jokin morfologinen kategoria lainautuu kuin että myös sen merkitsin lainautuu. Balkanin kieliliiton kielissä (ks. luku 3.4.) on paljon samankaltaisia morfosyntaktisia kategorioita mutta lainautuneita kieliopillisia morfeemeja on vain vähän. Esimerkkejä tällaisistakin kyllä löytyy: romania on lisännyt maskuliinin vokatiivin eli puhuttelusijan (joka esiintyi jo latinassa) rinnalle feminiinin vokatiivin, jonka pääte -o (esim. soro 'sisko!') on laina slaavilaisista kielistä (Feuillet 20I2, I82). 
Kreikan Traakiassa puhuttava romanikieli on lainannut turkista paitsi epäsuoran evidentiaalin (tiedon lähdettä ilmaisevan kieliopillisen muodon) myös sen merkitsimen -miş allomorfisessa asussa muš; romanikielessä se ei kuitenkaan ole sidonnainen vaan vapaa morfeemi ('kuulemma', 'muka', Adamou 20I2, 24-25), joten sekään ei ole täydellinen esimerkki taivutusmorfeemin lainautumisesta. (Vrt. myös itäslaavista suomeen lainattuun johtomorfeemiin -nik > -niekka, joka suomessa on pikemminkin yhdyssadan jälkiosa kuin johdin, sillä se ei mukaudu vokaalisointuun, esim. taitoniekka, kynäniekka.)

Silloin kun kieliopillisen kategorian ilmaisu on analyyttinen eli perifrastinen (esimerkiksi syntaktisten suhteiden ilmaiseminen prepositioilla tai aikamuotojen ilmaiseminen apuverbillä), sen lainautuminen muistuttaa syntaktista lainautumista. Euroopan kielissä, varsinkin pitkin maanosan rannikkoalueita, esiintyy perifrastisia perfektitempuksia, joiden merkitys on varsin samankaltainen ja jotka muodostetaan partisiipista, johon liittyy apuverbi 'olla' (kuten suomessa) tai 'omistaa' (kuten ruotsissa; ks. Lindstedt 2000). Itse apuverbin äänneasu ei ole kielestä toiseen sama mutta perfektin muodostustapa on.

Tutkittaessa kielikontaktin vaikutuksia historiallisessa kielitieteessä keskeinen metodologinen kysymys on todistustaakka: vaativatko kontaktilähtöiset muutokset vai kielensisäiset muutokset erityistä todistelua, jos kumpikin selitys olisi periaatteessa mahdollinen. Perinteisesti kielentutkimuksessa on suosittu kielensisäisiä muutoksia nollahypoteesina, jota ei tarvitse erikseen todistaa, mutta sanojen lainautumista on sentään pidetty normaalina. Sellaisten sanaparien kuin ruotsin gata ja suomen katu, tai ruotsin pojke ja suomen poika, kohdalla lainautuminen on itsestään selvää, varsinkin kun ruotsin ja suomen välillä on paljon tällaisia sanapareja. Silloinkaan lähdekieli ja lainautumisen suunta ei ole aina itsestään selvä: suomen katu on lainaa ruotsista (mikä onkin ollut vallitseva lainaussuunta), mutta ruotsin pojke puolestaan on lainaa suomesta (ja sen samankaltaisuus englannin boy-sanan kanssa on siis pelkkää sattumaa).

Nykyään kieliopillisten piirteitten lainautumiseen sinänsä ei enää suhtauduta epäilevästi, mutta yleisesti voi sanoa, että mitä vaikeammin lainautuvista piirteistä on kysymys, sitä paremmin pitää yrittää kuvata 
sitä sosiaalista tilannetta, jossa lainautuminen tai muu kontaktivaikutus on voinut tapahtua. Lainasanojen osalta riittää, että kielten kontakti on ylipäätään ollut mahdollinen - lainasanojen laatu voi sitten itsestään kertoa meille enemmän kontaktin luonteesta (ks. luku 3.3.). Sen sijaan esimerkiksi perfektitempuksen lainautumisen olettaminen edellyttää enemmän tietoa kontaktitilanteen laajuudesta ja pituudesta, kaksikielisten puhujien olemassaolosta ja kirjallisten traditioiden roolista yhteiskunnassa, varsinkin kun perifrastinen perfekti voi toki aina syntyä myös kielen sisäisten muutosten seurauksena.

Jos sama piirre esiintyy useammassa kuin kahdessa naapurikielessä, kontaktilähtöisyyden todennäköisyys kasvaa voimakkaasti, vaikkei piirteen lähdekieltä aina voisi osoittaa (vrt. luku 3.4. kieliliitoista). Euraasiassa on Balkanilta pitkälle Aasiaan ulottuva alue, jonka kielissä esiintyy tiedon lähdettä ilmaiseva evidentiaalisuuskategoria (Haarmann I970; de Haan 20I3). Alueen länsipään kieliin bulgariaan, makedoniaan ja albaniaan kategoria on selvästikin tullut turkista. Jonkinlaisista kieli-isänmaallisista syistä esimerkiksi osa bulgarialaisista lingvisteistä on halunnut pitää kielensä evidentiaalisuutta sisäsyntyisenä viitaten siihen, että evidentiaalisuus on kehittynyt myös moneen sellaiseen maailman kieleen, joka ei ole ollut missään yhteydessä turkkiin. Yksittäisen kielen kohdalla onkin aina mahdollista, että se on kehittänyt evidentiaalisuuden sisäisistä syistä, mutta on hyvin epätodennäköistä, että tällaiset kielet täysin sattumalta olisivat naapurikieliä, jotka muodostavat yhtenäisen alueen. Siksi kontaktiselitys on tässä tapauksessa uskottavampi.

\subsection{Kontaktitilanteiden synkroninen tutkimus}

Joskus kielikontakti-ilmiön asetelma tunnetaan hyvin ja siihen vaikuttavia tekijöitä voidaan havainnoida nykyhetkessä. Tällainen synkroninen kielikontaktien - tai usein pikemmin monikielisten käytänteiden - tutkimus on tyypillisesti kiinnostunut kontakti-ilmiöiden sekä erilaisten monikielisten tilanteiden analyysista sekä näistä tilanteista sosiaalisina ja yhteiskunnallisina ilmiöinä. Tällaisia tutkimusaloja ovat muun muassa akkommodaation ja koodinvaihdon (engl. code switching) tutkimus, 
monikielisyystutkimus sekä kielenvaihdon (sa. Sprachwechsel, engl. language shift) tutkimus. Huolimatta eriytyneestä ja usein soveltavammasta tutkimusperinteestään toisen kielen oppimisen tutkimus tarkastelee niin ikään monen muun kielikontakti-ilmiön kannalta keskeisiä prosesseja.

Kaikkien edellä mainittujen tutkimusalojen piirissä on mahdollista tarkastella kohteena olevia ilmiöitä myös menneisyydessä, esimerkiksi toisen kielen oppimisen tutkimuksessa voidaan käyttää pitkittäisaineistoja kielitaidon karttumista mitattaessa. Diakronisesta kontaktitutkimuksesta nämä lähestymistavat kuitenkin tyypillisesti eroavat selittävien ja selitettävien tekijöiden osalta. Siinä missä esimerkiksi lainasanan eri murremuodot ja levikki tai toisesta kielestä lainatun rakenteen kieliopillinen rooli tunnetaan hyvin, lainautumiseen johtanut sosiolingvistinen asetelma ja muut tekijät ovat usein hämärän peitossa. Synkronisessa tutkimuksessa tarkastelun keskiössä ovat monikieliset käytänteet, ja tutkimusaineistoa on mahdollista kartuttaa haastatteluin ja jopa kokeellisesti, jolloin itse kontakti-ilmiöön vaikuttavia taustatekijöitä voidaan suoraan säädellä. Usein on kuitenkin kiistanalaista tai epäselvää, missä määrin havaitut synkroniset ilmiöt vaikuttavat kielenmuutokseen pidemmällä tähtäimellä.

Akkommodaatio tarkoittaa sitä, että puhujat modifioivat ilmaisuaan keskustelukumppanista riippuen. Koska akkommodaatiotutkimus tyypillisesti tarkastelee kahden puhujan vuorovaikutusta, on sen tutkimuksessa mahdollista soveltaa muun muassa kokeellisia menetelmiä (ks. Kokeellinen fonetiikka tk.). Tarkasteltavien selittävien tekijöiden osalta tutkimusasetelmat ovat usein samanlaisia kuin sosiolingvistiikassa (ks. Sosiolingvistiikka tk.). Perinteisesti akkommodaation tutkimus on keskittynyt äänteelliseen modifiointiin vuorovaikutustilanteessa samaa kieltä puhuvien kesken, mutta modifioinnin on todettu koskevan myös muita kielen osa-alueita ja olevan keskeistä myös ei-äidinkielisten ja äidinkielisten sekä kielen eri varieteettien puhujien välisessä kielellisessä vuorovaikutuksessa. Eräs esimerkki akkommodaatiosta on aikuisille kielenoppijoille suunnattu puhe (engl. foreigner talk), jonka roolia on pohdittu kieliliittotyyppisten ilmiöiden taustalla (ks. esim. Joseph 20I0, 624-628). Peter Trudgill (i986) on puolestaan tarkastellut 
akkommodaation merkitystä kielenmuutoksessa murrekontaktien osalta.

Koodinvaihto on monikielisille yhteisöille tyypillinen ilmiö, jossa puhuja käyttää elementtejä useammasta kielestä tai kielimuodosta saman puhetilanteen aikana. Koodinvaihdon tutkimus tarkastelee usein samantyyppisiä sosiolingvistisiä tekijöitä kuin akkommodaatiokin. Vaikka koodinvaihtoa on mahdollista tutkia myös vaikkapa kaunokirjallisessa korpuksessa, tyypillisesti tutkimuksessa käytetään kenttätyössä hankittua keskusteluaineistoa (ks. Kielten dokumentointi ja kieliopin kuvaus; Antropologinen lingvistiikka; Haastattelu aineistonkeruun metodina sosiolingvistiikassa tk.). Vaikka alalla ei vallitse yhtenäistä näkemystä koodinvaihdon ja sanaston lainautumisen suhteesta, on selvää, että molemmissa on kyse samankaltaisista prosesseista (ks. esim. Muysken 2000, 75-78).

Kielenvaihto eli tilanne, jossa puhujayhteisö siirtyy käyttämään toista kieltä kuin aiemmin, on jo varhain tunnettu kielisosiologinen asetelma - pohjautuvathan erilaiset substraattiselitykset juuri siihen. Käynnissä olevaa kielenvaihtoa alettiin kuitenkin tutkia puhujayhteisön ja yksilön kannalta vasta I900-luvun loppupuoliskolla (ks. esim. tutkimuksen klassikko, Fishman I964). Kielenvaihtoon liittyvä keskeinen käsite on kielikuolema (engl. language death, language loss; prosessiin viittaavana myös language obsolescence). Kielikuolema tarkoittaa tilannetta, jossa kieli ei enää välity sukupolvelta toiselle ja viimeisten puhujien kuollessa myös kieli katoaa. Kielikuoleman yhteydessä havainnoidaan usein käyttöalan kapenemisesta ja puhujayhteisön harvenemisesta johtuvia muutoksia kielessä (ks. Palosaari \& Campbell 20ıı, ııo-Iı6). Samankaltaisia muutoksia tarkastellaan myös ensikielen attrition tutkimuksessa, jossa huomio on tyypillisesti yksilön ensikielen muutoksissa esimerkiksi muutettaessa alueelle, jossa valtakieli on jokin muu (ks. esim. Schmid 20II).

Kaksi- ja monikielisyyttä tutkitaan lukuisista eri näkökulmista (ks. esim. Edwards I994). Varhaislapsuuden monikielisyyden tutkimuksen kysymyksenasettelut ja metodiikka ovat usein samoja kuin kielen omaksumisen (engl. language acquisition) tutkimuksessa. Sosiolingvistisessä monikielisyyden tutkimuksessa tarkastelun kohteena ovat monikieliset 
yhteisöt ja yksilöt. Näiden lähestymistapojen piirissä tutkitaan usein kieli-identiteettiä ja monikielisyyttä resurssina sosiaalisessa vuorovaikutuksessa. Tällaisessa tarkastelussa kontaktilähtöiseen kielenmuutokseen ja esimerkiksi koodinvaihtoon liittyvä terminologia ja oletus diskreeteistä, selkeärajaisista kielimuodoista ovat saaneet osakseen kritiikkiä. Eritoten ilmiöiden diakroniaa tutkittaessa on aina tehtävä yleistyksiä kielistä, puhujayhteisöistä ja puhujista, mikä ei aina tee oikeutta esimerkiksi niille monille tekijöille, jotka vaikuttavat yksilön kielenkäyttöön. Tämä kritiikki on synnyttänyt esimerkiksi sellaisen käsitteen kuin kieleily (engl. languaging) kuvaamaan monikielisen yksilön toimintaa (kieleilyn ja kielikontaktin suhteesta ks. Lehtonen 2015, 304-307; ks. myös Lingvistinen etnografia toimintayhteisöissä tk.).

Diakroninen ja synkroninen kielikontaktien tutkimus täydentävät toisiaan: on oletettava, että kaikkien historiallisten kontaktimuutosten taustalla ovat perusluonteeltaan samankaltaiset monikieliset käytänteet, joita on mahdollista havaita nykyhetkessä. Tästä huolimatta diakronisen ja synkronisen tason yhdistäviä, uskottavia kontaktilähtöisen kielenmuutoksen malleja on olemassa varsin vähän. Mainita voi kuitenkin kaksi eritoten koodinvaihdon tutkimuksesta ammentavaa kontaktilähtöisen kielenmuutoksen mallia, Carol Myers-Scottonin (2002) ja Pieter Muyskenin (2013) mallit, joiden molempien keskiössä on kaksikielisen yksilön kielenkäyttö.

\subsection{Kontaktien historian tarkastelu niiden tulosten valossa}

Kielikontakteja voidaan joskus tutkia myös silloin, kun meillä ei ole juuri mitään historiallista tietoa kontaktitilanteesta. Paras esimerkki tästä on taas lainasanatutkimus: jos tietyt sanat pystytään äännehistoriallisin ja muin kielihistoriallisin argumentein osoittamaan lainasanoiksi, ne kertovat itsessään kontaktin tapahtuneen, ja sanojen merkitykset voivat tällöin kertoa paljon muinaisen kontaktin luonteesta. Ulkoisia ehtoja ei oikeastaan ole muita kuin se, että kyseisten kielten varhaisemmat muodot ovat voineet olla kosketuksissa keskenään eikä niitä ole esihistoriallisena aikana puhuttu esimerkiksi eri maanosissa. Kielten 
puhuma-alueitten ei enää nykyään tarvitse olla kosketuksissa keskenään; esimerkiksi saamelaiskielissä on indoiraanisia lainasanoja.

Lainasanatutkimuksen ansiosta tiedämme suomalaisten kielellisten esi-isien muinaisista kontakteista ensin arjalaisten eli indoiraanisten kielten puhujien, sitten balttilaisten kielten puhujien ja vielä germaanisten kielten (ei vielä ruotsin) puhujien kanssa - näiltä kaikilta olemme saaneet paljon keskeistä kulttuurisanastoa, mutta koska nämä kontaktit ovat tapahtuneet tuhansien vuosien aikana ennen ajanlaskumme alkua, meillä ei olisi niistä juurikaan tietoa ilman näitä lainasanoja (ajoituksesta ks. esim. Kallio 2006b). Myöhemmistä suomalaisten kontakteista itäslaavien kanssa on saatu jo ainakin jotain historiallista tietoa, mutta tässäkin tapauksessa lainasanatutkimus voi täydentää historian antamaa kuvaa. Sellaiset slaavilaiset lainat kuin akkuna (> ikkuna), lusikka, palttina, värttinä, turku ja suntio vastaavat äänneasultaan vanhimmissa slaavilaisissa teksteissä esiintyviä sanoja ja ovat osittain jopa niitä arkaaisempia. Ne kertovat itämerensuomalais-slaavilaisten kontaktien alkaneen verrattain varhain, viimeistään ajanlaskumme ensimmäisen vuosituhannen puolessavälissä (ks. esim. Kallio 2006a), ja samalla ne antavat vahvistuksen monelle sellaiselle kantaslaavin äännepiirteelle, joka muuten jäisi kokonaan vertailevan rekonstruktion varaan (ks. Historiallinen ja vertaileva kielentutkimus tk.). Kaikki lainasanat kuvastavat myös aikansa materiaalista ja henkistä kulttuuria (ks. yleisesityksiä lainautumisesta: Häkkinen I990; Haspelmath \& Tadmor 2009).

Kieliopin muutos on huomattavasti vaikeampi osoittaa kontaktilähtöiseksi, jos meillä ei ole historiallista tietoa kontaktitilanteesta. Mikä tahansa kieliopin piirre on voinut syntyä kielen sisäisen kehityksen tuloksena, ja kieliopin piirteet eivät koskaan ole niin ainutkertaisia kuin sanojen äänneasu. (Useamman kuin kahden vierekkäisen kielen samankaltainen kielioppipiirre on jo todennäköisemmin kontaktilähtöinen, ja silloin puhumme kieliliitoista - ks. luku 3.4.) Toisin kuin lainasanat kielioppipiirre, joka on mahdollisesti lainautunut, ei myöskään kerro juuri mitään lainautumisajan kulttuurisen kontaktin laadusta, koska kieliopin rakenteella ja kulttuurilla ei ole suoraa suhdetta (vrt. kuitenkin luvut 3.5. ja 3.6. kontaktitilanteen ja kieliopillisen typologian suhteesta). 
Jos halutaan antaa varoittava esimerkki siitä, mitä seuraa metodologisten vaatimusten höllentämisestä esihistoriallisten kielikontaktien tutkimuksessa, äärimmäinen tapaus on aikoinaan paljon julkisuutta saanut foneetikko Kalevi Wiikin (2002) teoria, jossa suuri osa eurooppalaisten kielten varhaisempaa historiaa selitettiin suomalais-ugrilaisen substraatin (ks. luku 2) avulla. Jos kaikki muutokset, jotka päällisin puolin tarkasteltuna voisivat olla kontaktilähtöisiä, myös oletetaan kontaktilähtöisiksi ilman mitään riippumatonta tukea, lopputuloksena on mielikuvituksellinen rakennelma, jolla on enää vähän yhtymäkohtia tunnettuihin faktoihin. Wiikin metodologisiin virheisiin kuului myös se, että hän surutta hylkäsi uniformitarianismin eli sen lähtökohdan, että menneisyydessä on oletettava vallinneen samojen säännönmukaisuuksien kuin nykyisyydessä, ellei meillä ole painavaa syytä olettaa muuta. Hänen mallissaan substraattivaikutus, lingua francan käyttö tai metsästäjä-keräilijöiden kielialueiden koko noudattivat menneisyydessä aivan eri lainalaisuuksia kuin nykyisin. (Wiikin teoksen kriittisiä arvioita on julkaistu useita, joista yksi on Lindstedt [2004].)

On kuitenkin olemassa lähestymistapa, jonka avulla naapurikielten kieliopillisia samankaltaisuuksia voidaan tarkastella jopa kaukaisen esihistorian näkökulmasta ilman, että sorrutaan perusteettomaan spekulointiin. Käänteentekevässä monografiassaan Linguistic Diversity in Space and Time Johanna Nichols (I992) osoitti, että monen kieliopillisen piirteen levinneisyys maailman kielissä korreloi kielten sijainnin kanssa koko maailman mittakaavassa. Monet piirteet muodostavat länsi-itäsuuntaisia kliinejä, toisin sanoen piirrettä kuvaava indeksi muuttuu paikan monotonisena funktiona. "Länsi" ja "itä" määräytyvät tässä maapallon asutushistorian mukaan: länttä ovat Afrikka, josta ihmislajin ekspansio alkoi, Lähi-itä ja Eurooppa, itää ovat puolestaan Australia ja Etelä-Amerikka, jotka olivat ekspansion pääteasemia, ja niiden välissä ovat Tyynenmeren rannikko ja Pohjois-Amerikka. Nicholsin selitys tälle on se, että itäiset piirteet olivat itäisempien kielten piirteitä jo kymmeniä tuhansia vuosia sitten, kun ekspansio alkoi, eli ne edustavat laajenevan ihmiskunnan eturintaman piirteitä, kun taas läntisemmät piirteet olivat leimallisia myöhemmin liikkeelle lähteneille ihmisryhmille (Nichols I992, 254-259). Toki kielet ovat omaksuneet uusia alueittain 
samankaltaisia piirteitä ihmiskunnan levittäytymisen jälkeenkin, mutta tällainen alueellinen konvergenssi ei olisi voinut tuottaa koko maailman mittaisia kliinejä.

Nichols (I992) liikkuu sellaisessa aikasyvyydessä, johon historiallis-vertaileva menetelmä ei ulotu (ks. Historiallinen ja vertaileva kielentutkimus tk.). Niinpä meillä ei ole mitään keinoa tietää, ovatko hänen löytämänsä vanhimmat alueelliset samankaltaisuudet kielisukulaisuuden vai kielikontaktin aiheuttamia - todennäköisesti kyse on kummastakin, mutta emme voi mitenkään tietää, missä suhteessa. Siitä huolimatta hän on saanut varsin vakuuttavia tuloksia. Vaikka kielikontaktien tutkimus siis edellyttää areaalisuuden eli maantieteen huomioon ottamista, areaalisuutta voidaan tutkia olettamatta mitään kielikontakteista. Seuraavassa kappaleessa palaamme kuitenkin sen verran pieniin aikasyvyyksiin, että areaalisuus ja kontaktit ovat liitettävissä toisiinsa.

\subsection{Areaalisuus: kieliliitot ja kontaktialueet}

Useimmiten kielikontaktien tutkimus selvittelee sitä, miten jokin piirre on lainautunut yhdestä kielestä toiseen, tai synkronisesti, miten jonkin kielen elementit käyttäytyvät ja mitä niillä tehdään puhuttaessa toista kieltä. Mikäli lainanantajakieli on luonteeltaan superstraatti eli prestiisiltään korkeampi varieteetti, lainautuminen on todennäköisesti yksisuuntaista eli toinen kieli on lainojen lähde ja toinen vastaanottaja (ks. kuitenkin luku 3.6. L2-puhujien vaikutuksesta). Jos kielten välillä vallitsee kuitenkin adstraattisuhde ja kumpikaan kieli ei merkittävästi dominoi, on varsin luonnollinen kysymys, mitä tapahtuu lainanantajakielelle itselleen. Mikäli lainautumisen taustalla on kahden erikielisen yhteisön vuorovaikutus, jossa osa molempien kielten puhujista osaa ainakin jossain määrin myös toista kieltä, voi lainautumista tapahtua molempiin suuntiin.

Kuten luvussa 2 todettiin, kielikontaktien tutkimuksen syntyyn liittyvät keskeisesti havainnot tietyillä alueilla puhutuista kielistä, joilla on paljon yhteisiä piirteitä, jotka eivät selity kielten sukulaisuudella. Tällaisten alueiden nimitykseksi vakiintui ıgoo-luvun puolivälissä kieliliitto, ja 
havaintoja tämän tyyppisistä kielellisistä alueista on tuon jälkeen tehty lukuisia. Tyypillistä näille havainnoille on se, että yhteisten piirteiden alkuperää ei tunneta, eli jaetut piirteet eivät selity esimerkiksi yhteisellä superstraatilla, mikä sekin voi kyllä johtaa samankaltaiseen lopputulokseen. Ajatellaan esimerkiksi Venäjän federaation vähemmistökieliä: lähes kaikki niiden puhujat osaavat myös venäjää, ja venäjästä voi näin ollen lainautua sama rakenne useampaan kieleen niin, että lainattujen piirteiden osalta vähemmistökielet saattavat alkaa muistuttaa toisiaan. Tällaista superstraattilähtöistä alueellista samankaltaisuutta ei kuitenkaan yleensä kutsuta kieliliitoksi.

Eräs ainakin teoreettinen mahdollisuus, joka voisi johtaa niin ikään kielten samankaltaistumiseen tietyllä alueella, on yhteinen substraatti. Mikäli useamman kielen historiassa on tapahtunut kielenvaihtoa ja taustalla on kaikissa sama substraattikieli, voivat muutokset olla samankaltaisia. Tällaisten selitysten ongelma on usein se, että niitä on melkein mahdotonta osoittaa oikeiksi kiistattomasti. Substraattiselitysten aiemman suosion taustalla lienee se, että substraatti oli varhaisimpia tunnettuja kielikontaktin tyyppejä ja muita mekanismeja tunnettiin huonosti. Ei ole kuitenkaan poissuljettua, etteikö jonkin tunnetun kieliliittoilmiön taustalla olisi ainakin osittain yhteinen substraatti. Esimerkiksi manner-Kaakkois-Aasian kieliliiton äänteelliset piirteet voivat hyvin selittyä mon-khmer-kielten (esim. vietnam) substraatilla (ko. kieliliitosta ks. Enfield 2005). Samaten Intian kieliliitolle luonteenomaiset retrofleksikonsonantit voivat olla perua dravidakielten substraattivaikutuksesta indoarjalaisissa kielissä (Intian kieliliitosta ks. Emeneau i956).

Jos siis kieliliiton taustalla on yleensä ristiinlainautuminen prestiisiltään suurin piirtein samanlaisten kielten välillä, onko kyseessä lopulta vain alue, jonka kielissä sattuu olemaan lainoja useammasta kielestä? Tällaista näkemystä edustaa esimerkiksi Lyle Campbell (2006), joka olisi valmis hylkäämään kieliliiton käsitteen ja puhumaan ainoastaan yksittäisten paikallisten lainojen kumuloitumisesta tietyllä alueella. Hieman samassa hengessä Bernd Heine ja Tania Kuteva (2006, 286-287) asettuvat vastustamaan kieliliittojen osalta usein käytettyä konvergenssin käsitettä, jolla kuvataan tilannetta, jossa kieliliiton kielten rakenteet lähentyvät toisiaan. Myös Heine ja Kuteva käsittelevät kieliopillisia 
kontakti-ilmiöitä yksittäisten lainautumisprosessien kautta, ja heidän luomassaan mallissa on aina selkeästi tunnistettava lainan antaja ja vastaanottaja.

Vaikka edellä mainittu kritiikki hyväksyttäisiin, tulee kuitenkin selittää, miksi joillain alueilla tällaista monensuuntaista lainautumista tapahtuu ja miksi toisilla taas ei. Lisäksi herää kysymys siitä, miksi esimerkiksi Balkanilla, jossa useamman alueen kielen historia tunnetaan melko hyvin, on kuitenkin usein mahdotonta määritellä jaetun piirteen alkuperää. Eräs tarjottu selitys on, että kieliliitto olisi sittenkin enemmän kuin yksittäisten lainautumisten summa: Jaetuilla piirteillä ei välttämättä ole Campbellin (2006) sekä Heinen ja Kutevan (2006) olettamaa selkeää lähdettä, vaan kieliliiton taustalla oleva sosiolingvistinen asetelma suosii ja levittää tietyntyyppisiä rakenteita. Balkanin kieliliiton osalta monet jaetut piirteet ovat analyyttisiä rakenteita, jotka ovat korvanneet kaikissa kielissä aiemmat synteettiset rakenteet (Lindstedt 20I9; Balkanin kieliliitosta suomeksi ks. Lindstedt 2009a, jossa kartan selitykset ovat kuitenkin vaihtuneet keskenään; ks. myös luku 3.6.).

Kieliliittojen tutkimus on osa niin kutsuttua areaalilingvistiikkaa, joka tarkastelee kielellisten piirteiden alueellista levikkiä. Useimmiten kieliliittojen tutkimuksessa on taustalla jonkinlainen historiallinen hypoteesi niiden syntyyn vaikuttaneista tekijöistä. Usein kuitenkin havaitaan, että jollakin tietyllä laajallakin, esimerkiksi mantereen kokoisella maantieteellisellä alueella kielet suosivat tietyntyyppisiä rakenteita. Tästä seuraa, että kielen puhuja-alueen maantieteellinen sijainti voi olla yhtä hyvä kielen rakenteen selittäjä kuin kielen kuuluminen johonkin kielikuntaan. Lauri Hakulinen (I968, 388-392) kiinnittää huomion siihen, että suomen kieli muistuttaa paljon muita eurooppalaisia kieliä sanastonsa rakenteeltaan johtuen lukuisista käännöslainoista. Östen Dahl (2008) laajentaa tarkastelun myös kielioppiin ja toteaa, että suomi on rakennepiirteiltään varsin eurooppalainen kieli verrattuna esimerkiksi idempänä puhuttuihin sukukieliinsä.

Suomen tapauksessa on selvää, että kielen rakenteiden osalta samankaltaisuuden täytyy olla seurausta kielikontakteista. Tämän tyyppisessä areaalilingvistisessä tarkastelussa kielikontaktit ovat kuitenkin vain yksi - joskin varteenotettava - kielipiirteiden alueellisen jakauman selittäjä. 
Kun tarkastellaan jonkin piirteen levikkiä ja aineistona on edustava otos maailman kielistä, ei voida poissulkea sitä, etteikö piirteen edustumien taustalla olisi myös muinainen kielisukulaisuus. Tällaiset typologiset piirteet eivät kuitenkaan itsessään kelpaa todistusaineistoksi kielisukulaisuudesta juuri sen vuoksi, että ne voivat levitä myös kontaktissa, ja kielisukulaisuuden todistamiseen tarvitaan aina historiallis-vertailevan kielitieteen menetelmiä säännöllisten äännevastaavuuksien löytämiseksi (ks. myös luku 3.3.; Historiallinen ja vertaileva kielentutkimus tk.).

Havainnot kielipiirteiden alueellisesti merkitsevästä levikistä ovat johtaneet siihen, että määrällinen kielitypologinen tutkimus pyrkii aina huomiomaan areaalisia tekijöitä tarkastellessaan kielen universaaleja (ks. Kielitypologian menetelmät tk.). Tähän tarkoitukseen käytetään erilaisia otoksia, joissa maapallo on jaettu eri kokoisiin makroalueisiin (menetelmästä ks. Dryer I989). Balkanin kaltaisten kieliliittojen tutkimuksen rinnalla mutta osittain myös siitä riippumatta on kehittynyt kooltaan huomattavasti suurempien makroalueiden tutkimus. Toisin kuin kieliliittojen makroalueiden synty on useimmiten sellaisessa aikasyvyydessä, että ei voida saavuttaa varmuutta siitä, juontuvatko jaetut piirteet kielikontakteista vai yhteisestä muinaisesta alkuperästä (ks. luku 3.3.). Pääasiassa kontaktioletuksiin perustuvat makrotason mallit kilpailevatkin usein selityksinä omnikomparativististen etäkielikuntien kanssa. Näillä tarkoitetaan kielikuntahypoteeseja, jotka perustuvat kielten pinnallisiin äänteellisiin samankaltaisuuksiin (ks. myös Historiallinen ja vertaileva kielentutkimus tk.).

\subsection{Kontaktikielet}

Kielten välinen kontakti voi johtaa siihen, että syntyy uusia kieliä, jotka eivät ole kontaktitilanteeseen osallistuneiden kielten tytärkieliä käsitteen perinteisessä merkityksessä (ks. Historiallinen ja vertaileva kielentutkimus tk.). Tällaisia uusia kieliä kutsutaan kontaktikieliksi - tosin termillä tarkoitetaan joskus mitä tahansa erikielisten välisessä kontaktissa käytettävää kieltä, mutta suppeammassa merkityksessä kontaktikielet eivät ole pelkästään käytössä kontaktitilanteessa, vaan ne ovat myös 
syntyneet siinä. Tällaisten kontaktikielten kolme päätyyppiä ovat pidginit, kreolit (kreolikielet) ja sekakielet. Niiden tutkimus on itsenäinen lingvistiikan ala, jolla on omat vakiintuneet julkaisukanavansa (esimerkiksi Journal of Pidgin and Creole Languages ja kirjasarja Creole Language Library, uudemmalta nimeltään Contact Language Library). Johdantotekstejä kontaktikielten tutkimukseen ovat esimerkiksi Bartens (2009), Thomason (200I, I57-22I) ja Arends, Muysken ja Smith (I995). Laajempi kokoomateos on Kouwenberg ja Singler (2008).

Pidginit eivät ole kenenkään äidinkieliä. Ne ovat syntyneet kahden tai useamman kielen puhujien kontaktitilanteessa, jossa eri kielten puhujat eivät ole osanneet toistensa kieltä mutta ovat joutuneet kommunikoimaan keskenään esimerkiksi kaupankäynnin vuoksi. Vastoin yleistä käsitystä pidginit eivät ole "sekakieliä", jotka olisivat syntyneet kahden tai useamman kielen yhteensulautumisesta. Niiden sanasto on useimmiten pääosin peräisin yhdestä, prestiisiltään korkeammasta kielestä, jota kutsutaan leksifioijaksi. Pidginien kielioppi puolestaan ei pohjaudu suoraan mihinkään muuhun kieleen vaan pikemminkin kuvastaa kommunikaation yksinkertaisia perustarpeita. Konkreettisessa kommunikaatiotilanteessa puhujien omat äidinkielet voivat toki vaikuttaa puhunnosten muotoon, esimerkiksi sanajärjestykseen. Morfologiaa pidgineissä on hyvin vähän tai ei ollenkaan.

Yksi tunnetuimmista pidgineistä oli lingua franca -niminen kieli, jota käytettiin Välimeren alueella ristiretkien ajalta I80o-luvulle asti (tätä ei pidä sekoittaa lingua franca -termin uudempaan käyttöön merkityksessä 'yhteiskieli', esimerkiksi "Englanti lingua francana", ks. luku 2.). Sen leksifioijana olivat romaaniset kielet, erityisesti italia. Suomea lähin vakiintunut pidginkieli oli russenorsk, jota norjalaiset ja venäläiset kalastajat ja kauppiaat käyttivät kaupankäynnissään Jäämeren alueella I7oo-luvun lopulta I900-luvun alkuun. Russenorsk oli siinä mielessä poikkeuksellinen pidgin, että sillä oli kaksi pääleksifioijaa, venäjä ja norja; sen lisäksi siinä oli esimerkiksi englantilaisia ja hollantilaisia sanoja, jotka merenkulkijoitten mukana ovat levinneet moneen muuhunkin maailman pidginiin. Russenorskiksi käyty keskustelu aloitettiin usein lauseella moja po tvoja 'minä puhun sinun kieltäsi', mikä viittaisi siihen, että norjalaisten mielestä russernorsk oli (eräänlaista) venäjää ja venäläisten 
mielestä (eräänlaista) norjaa. Täydellisin lähde russenorskista on Broch ja Jahr (I984).

Jotkin pidginit ovat saaneet äidinkielisiä puhujia; näin kävi erityisesti tietyissä siirtomaaolosuhteissa, esimerkiksi viljelyksillä, joilla työskenteli eri seuduilta kotoisin olevia orjia. Kun pidgin saa äidinkielisiä puhujia, sen käyttöala laajenee ja rakenne täydellistyy muitten äidinkielenä käytettävien ihmiskielten mukaiseksi, jolloin siitä tulee kreoli. Kreolikielellä on siis äidinkielisiä puhujia, mutta joskus aikaisemmin sillä ei ole ollut. Historiallisen kielentutkimuksen kannalta sanotaan, että sen historiassa on ollut sukupolvien välisen siirron katko (engl. broken transmission) eikä se asetu minkään kieliperheen sukupuuhun samassa mielessä kuin katkeamatta siirtyneet kielet. Historiallis-vertailevaa menetelmää (ks. Historiallinen ja vertaileva kielentutkimus tk.) ei siis voi suoraan soveltaa kreolien historian tutkimukseen.

Tunnettu esimerkki kreoleista on haitinkreoli, jonka leksifioija on ranska (ja jota ei siis pidä sekoittaa Haitilla puhuttavaan ranskan varieteettiin). Alankomaihin kuuluvilla Karibianmeren saarilla puolestaan puhutaan papiamentoa, jonka pääasiallinen leksifioija on portugali, mutta jossa on myös paljon espanja- ja hollantiperäistä sanastoa. Suomalaisten päiväkotien sormileikkilaulua "Täällä liikkuu viisi sormea" (san. Soili Perkiö) lauletaan usein myös eksoottisella vieraalla kielellä (sinku dede mi tin na mi man 'viisi sormea minulla on kädessäni'), mutta juuri kukaan ei Suomessa tunnista kieltä papiamentoksi.

Englantilaispohjaisia eli englannin leksifioimia kreoleja ovat esimerkiksi tok pisin, joka on yksi Papua-Uusi-Guinean virallisista kielistä, ja Länsi-Afrikan pidginenglanti, jolle BBC vastikään avasi oman uutiskanavan ${ }^{\mathrm{I}}$. Kumpikaan kieli ei siis nimestään huolimatta ole enää pidgin vaan kreoli.

Jotkut tutkijat ovat sitä mieltä, ettei kreolin synty aina edellytä edeltävää pidginiä. Thomason ja Kaufman (I988, I47-I66) ovat esittäneet, että esimerkiksi erikielisten orjien keskuudessa saattoi tapahtua "äkillinen kreoloituminen": heti ensimmäisten orjille syntyneiden lasten (yhdeksi) äidinkieleksi tuli heidän vanhempiensa puutteellisesti oppima siirtomaaisäntien kieli, ja kreoli syntyi ilman edeltävää pidginvaihetta. Ainakin osittain tämä on myös määrittelykysymys, sillä irrallisista yrityksistä 
kommunikoida huonosti osatulla kielellä on jatkumo rakenteeltaan jossakin määrin vakiintuneeseen pidginiin. Varmaankaan kreolin syntyminen ei ole aina edellyttänyt vakiintunutta pidginiä.

On myös mainittava se käsitys, jonka puolesta on argumentoinut esimerkiksi Salikoko Mufwene (2008, II5-20I), että kreolit eivät muodosta mitään poikkeuksellista ryhmää ihmiskielten joukossa. Hänen mukaansa latinan muuntuminen ranskaksi kielenvaihdon kautta ja kielikontaktien vaikutuksen alaisena oli aivan samankaltainen prosessi kuin ranskan muuntuminen haitinkreoliksi, joka siis kuuluu romaanisten kielten sukupuuhun yhtenä normaalina haarana. Kreolikielet on eroteltu omaksi ryhmäkseen vain niiden puhujien alhaisen yhteiskunnallisen statuksen vuoksi. Mufwenen ajatukset ovat terveellinen muistutus siitä, että kontaktilingvistiikan ilmiöt eivät voi olla täysin erilaisia kreoleiden synnyssä kuin muitten ihmiskielten kohdalla. Toisaalta Mufwene ei kuitenkaan ota kantaa siihen periaatteelliseen metodologiseen eroon, ettei kreoleita voi käyttää historialliseen rekonstruktioon (esim. tok pisiniä kantagermaanin rekonstruktioon) samalla tavalla kuin muita kieliä (Thomason \& Kaufman I988, 200-20I). Niiden historiassa on siis ollut poikkeuksellisen uudelleenjärjestäytymisen vaihe, vaikkeivät kaikki tutkijat halua kutsua sitä katkenneeksi siirroksi. McWhorter (2018) argumentoi vahvasti sen puolesta, että kreolit ovat kuin ovatkin alkuperältään ainutlaatuisia ja itse asiassa ainoita aidosti uusia ihmiskieliä.

Yleisen kontaktilingvistiikan kannalta on tässä yhteydessä hyvä varoittaa muutamasta termistä. Kreoloituminen tarkoittaa pidginin kohdalla sitä, että se nativisoituu eli saa äidinkielisiä puhujia ja alkaa heidän puheyhteisössään muuttua. Kreoloitumiseen liittyy siis rakenteen ja funktioiden kehittyminen ja monimutkaistuminen. Mutta jos asiaa tarkastellaan leksifioijakielen kannalta, "kreoloituminen" saattaakin päin vastoin tarkoittaa rakenteen yksinkertaistumista, koska kreoleilla on yksinkertaisempi kielioppi kuin leksifioijalla (tosin tästäkin on eri käsityksiä, ks. luku 3.6.). Varsinkin Thomasonin ja Kaufmanin (I988) esittämä "äkillinen kreoloituminen" olisi ennemmin yksinkertaistumista kuin monimutkaistumista. Dekreoloituminen taas tarkoittaa sitä, että kreoli alkaa rakenteeltaan lähestyä leksifioijaa ja lainaa siltä sanastoa ja kielioppia, koska sillä on suurempi prestiisi. 
Sen sijaan on syytä välttää kreoloituminen-termin käyttöä kuvaamaan mitä tahansa kielen rakenteen radikaalia muutosta kontaktitilanteessa, jos tuloksena ei ole kreolikieli. Esimerkiksi afrikaansia ei pidä kutsua "kreoloituneeksi hollanniksi", koska kielen siirto sukupolvelta toiselle ei hollannin ja afrikaansin välissä ole missään vaiheessa katkennut. Jos halutaan korostaa ei-äidinkielisten puhujien (todennäköisesti vahvaa) roolia sen kehityksessä (Thomason \& Kaufman I988, 25I-256), tarjolla on sellaisia termejä kuin kreoloidi ja semikreoli. Tämäkin liittyy seuraavassa luvussa 3.6. käsiteltävään kysymykseen ei-äidinkielisten puhujien merkityksestä kielen typologisen muutoksen kannalta.

Termit superstraatti ja substraatti ovat kreolistiikassa käytössä hieman eri merkityksessä kuin muussa kontaktilingvistiikassa. Superstraatilla tarkoitetaan useimmiten leksifioijaa tai muuta kreoliin vaikuttavaa, prestiisiltään korkeaa kieltä. Substraatti taas tarkoittaa niitä kieliä, jotka olivat kreolia edeltävän pidginin puhujien äidinkieliä. Yksi keskeinen kysymys kreolistiikassa on, missä määrin kreolien kielioppi on peräisin superstraatista, substraatista tai kielellisistä universaaleista.

Termiä sekakieli (engl. mixed language) käytetään kontaktilingvistiikassa paljon vähemmän kuin yleisessä kielenkäytössä. Se, että jokin kieli on lainannut paljon sanastoa toiselta, ei tee siitä sekakieltä: englanti on yhä germaaninen kieli, vaikka se on lainannut paljon ranskasta, jiddiš on myös germaaninen kieli slaavilaisista ja heprealaisista lainoistaan huolimatta, ja albania on yhä oma haaransa indoeurooppalaisessa kieliperheessä, vaikka sen suoraan kantakielestä peritty sanasto on supistunut pieneksi romaanisten ja slaavilaisten lainojen tieltä.

Kansanomaisissa esityksissä pidginit ja kreolit selitetään joskus kahden tai useamman kielen sekoituksiksi, mitä ne siis missään tapauksessa eivät ole. Maailmassa on kuitenkin muutamia todellisia sekakieliä, jotka muodostavat pidginien ja kreolien ohella kontaktikielten kolmannen ryhmän (Thomason 200I, I96-22I). Ne eivät ole syntyneet erikielisten väestöjen kohtaamisessa vaan yhden väestöryhmän keskuudessa kahden kielen kohdatessa. Sen sijaan, että ryhmä hylkäisi alkuperäisen kielensä valtakielen levitessä heidän alueelleen, se luokin uuden kielen, jossa on elementtejä kummastakin. 
Sekakielille on tyypillistä, että kielen pääkomponentit, esimerkiksi sanasto, substantiivien morfologia tai verbien morfologia, voivat olla selvästi eri lähteistä. Esimerkiksi Mednyisaaren aleutti, jota puhuttiin ı8०o-luvulla ja vielä I9०o-luvullakin pienellä Tyynenmeren saarella Kamtšatkan itäpuolella, oli muuten sanastoltaan ja kieliopiltaan aleuttia, mutta aleutin monimutkainen finiittiverbien morfologia oli korvattu venäjän mukaisella verbitaivutuksella. Ecuadorissa puhuttavan media lengua -kielen kielioppi puolestaan pohjautuu ketšuaan mutta sanasto espanjaan; puhujat muodostavat oman ryhmänsä, jotka eivät identifioidu ketšuan tai espanjan puhujiksi. Myös nk. pararomanikieliä, joissa romanikielen sanasto liittyy paikallisen kielen (esimerkiksi englannin tai suomen) kielioppiin (Matras 2002, 242-248), voi pitää sekakielinä. Tässäkin vain on ongelmana, että määrittelystä riippumatta termi sekakieli tuo puhujille itselleen ja laajemmalle yleisölle aina negatiivisia assosiaatioita.

Sekakielten tutkimuksen kannalta mielenkiintoinen kielimuoto on helsinkiläinen stadin slangi - nimenomaan sen alkuperäinen, I80oja I90o-lukujen vaihteessa puhuttu versio, jossa kielioppi oli suomen mukainen mutta sanasto pääosin ruotsista (Kallio 2007). Se ei ollut yllä kuvatun kaltainen sekakieli siinä mielessä, että sillä olisi ollut äidinkielisiä puhujia, mutta se oli kuitenkin tietyn ryhmän identiteetin merkitsin. Toisaalta se ei oikein muistuta pidginiäkään, koska sillä oli monimutkainen, yhdestä kielestä lainattu kielioppi. Joka tapauksessa sitä voidaan pitää suomen ja ruotsin kontaktista syntyneenä varieteettina - kummallakin kielellä oli tuohon aikaan suunnilleen yhtä paljon puhujia Helsingissä (Kallio 2007, I76) - mutta on määrittelykysymys, oliko se uusi kontaktikieli vaiko vain suomen erikoinen kontaktivarieteetti (eli varieteetti, jossa kontaktivaikutus on huomattavan voimakas saman kielen muihin varieteetteihin verrattuna). Koska Kallio pitää kieliopillisia elementtejä kielisukulaisuuden määräävänä tekijänä, hän pitää stadin slangia suomalais-ugrilaisten kielten sukupuuhun kuuluvana. Tällä perusteella media lenguakin olisi ehkä ketšuan sukukieli, ei sekakieli, mutta Mednyisaaren aleutin luokittelu aleutin tai venäjän sukukieleksi olisi jo mielivaltaista, koska jako kulkee keskeltä kielioppia.

Lindstedt (2009b) on esittänyt, että kontaktikielten tutkimuksen metodeja voidaan käyttää jopa esperanton alkuperän, muutoksen ja 
äidinkielistymisen tutkimuksessa. Esperanton peruskielioppi ja -sanasto suunniteltiin tietoisesti, mutta esperantonkielisissä teksteissä ja sen puhujien kielenkäytössä on runsaasti ilmiöitä, jotka eivät kuvasta julkaistuja suppeita kielioppeja vaan ovat sen kieliympäristön vaikutusta, jossa kieltä on käytetty. Esperantoa voidaan tässä mielessä pitää kontaktikielenä, jossa on romaanis-germaaninen superstraatti ja slaavilainen substraatti (kreolistiikassa käytetyssä merkityksessä, ks. ylh.). Äidinkieliset esperanton puhujat ovat jossain määrin samassa tilanteessa kuin pidginiä kreoloivat varhaiset puhujat.

Kielikontaktien tutkimuksen kannalta tärkein kontaktikielten antama opetus on, ettei ihmiskielessä ole mitään osaa, johon tietynlainen kontaktitilanne ei voisi vaikuttaa radikaalistikin. Kreolistiikan piirissä syntyneillä tavoilla tarkastella kielten sosiohistoriallista taustaa ja kielen siirtoa sukupolvelta toiselle on paljon annettavaa myös sellaisten varieteettien tutkimukselle kuin afrikaans tai stadin slangi, jotka eivät ainakaan ilmeisen selvästi ole itse kontaktikieliä tämän osan alussa kuvatussa suppeammassa mielessä.

\subsection{Kielikontaktien vaikutus kielen tyyppiin}

Kontaktit eivät tuo kieleen pelkästään yksittäisiä toisista kielistä lainattuja piirteitä, vaan ne voivat vaikuttaa myös kielen koko rakenteeseen. Tämä liittää kontaktien tutkimuksen kielitypologiaan ja sen piirissä käytyyn keskusteluun kielten kompleksisuudesta eli monimutkaisuudesta ja sen vähenemisestä eli yksinkertaistumisesta.

Strukturalistisessa kielentutkimuksessa oli pitkään vallalla aksiooma, jonka mukaan kaikki kielet ovat yhtä monimutkaisia (ks. Kusters 2003, I-5). Tämä oli aikanaan ymmärrettävä reaktio niihin varhaisempiin etnosentrisiin käsityksiin, joiden mukaan useimmat kielet ovat jotenkin primitiivisempiä kuin indoeurooppalaiset ja mahdollisesti seemiläiset kielet (vaikka jo Darwin tiesi tämän käsityksen vääräksi, vrt. "[t]he perfectly regular and wonderfully complex construction of the languages of many barbarous nations"; Darwin I874, luku III, jossa viitataan kielitypologian pioneeriin Friedrich Schlegeliin). Koska kielihistoriassa on 
kuitenkin helppo löytää esimerkkejä kielen jonkin osan ilmeisestä yksinkertaistumisesta (esimerkiksi latinan monimutkaisen taivutusmorfologian yksinkertaistumisesta ja kadosta romaanisissa kielissä), yhtäläisen kompleksisuuden aksioomaa oli täydennettävä sillä oletuksella, että yksinkertaistavan muutoksen jotenkin kompensoi kielen jonkin toisen komponentin monimutkaistuminen. Tällaiselle oletukselle ei kuitenkaan ole löytynyt empiiristä tukea, eikä kukaan myöskään ole voinut esittää, millainen koko kielen kattava säätelymekanismi pitäisi huolen tällaisesta kompleksisuuden kokonaishallinnasta (Trudgill 20II, I5-I6). Kokonaiskompleksisuuden mittaaminen olisi sitä paitsi vaikeaa, koska emme tiedä, mitkä kaikki piirteet pitäisi ottaa huomioon tai miten asettaa kielen eri tasoja kuvaavat mittarit samalle asteikolle (Miestamo 20I7, 238).

Nykyään on voittamassa alaa se käsitys, että on mielekästä puhua eri kielten kompleksisuuden eroista, kunhan määritellään, millaista kompleksisuutta tarkoitetaan. Dahl (2004, I9-55), McWhorter (20II, I-2) ja Trudgill (20II, I5-24) ovat analysoineet kompleksisuus-käsitteen eri puolia. Usein esitettyjä parametreja ovat I) sääntöjen monimutkaisuus, eli kuinka laaja on kieliopin jonkin osan tyhjentävä kuvaus, 2) läpinäkyvyyden puute kieliopissa tai leksikossa, eli kuinka kaukana ollaan "yksi merkitys - yksi muoto" -periaatteesta (vrt. Anttila I972, I00-IO2, passim), ja 3) redundanssi, eli vaatiiko kielioppi merkitsemään seikkoja, jotka selviävät kontekstista (paradigmaattinen redundanssi) tai jotka on jo merkitty toisessa kohtaa lausetta (syntagmaattinen redundanssi). Redundanssi lisää ennen kaikkea kielen puhujan prosessointitaakkaa, mutta kuulijan kannalta se on viestin ymmärtämistä helpottava. Miestamo (2008; 20I7) on esittänyt, että kompleksisuuden mittaaminen on redusoitavissa kahteen parametriin: kuinka monia semanttisia tai pragmaattisia erotteluja kielessä merkitään, ja kuinka kaukana ollaan "yksi merkitys - yksi muoto" -periaatteesta.

Kompleksisuus korreloi varsin pitkälti sen kanssa, kuinka helppoa kieltä on oppia vieraana kielenä kriittisen kielenomaksumisiän jälkeen, mutta tämä L2-vaikeus on kuitenkin erillinen, empiirisesti tutkittavissa oleva suure, joka on ainakin osittain sidoksissa oppijan ensikielen rakenteeseen. Jos kielessä on foneemisia tooneja (kuten kiinassa) tai 
tonaalisia aksentteja (kuten ruotsinruotsissa), ne eivät välttämättä tee kielen fonologian kuvauksesta kovin paljon monimutkaisempaa mutta saattavat silti olla huomattavan vaikeita L2-oppijan kannalta.

Edellisessä luvussa 3.5. käsiteltyjen pidginien ja kreolien tutkimuksessa yksi keskeinen kysymys on ollut, ovatko tällaiset kontaktikielet rakenteeltaan jossakin mielessä yksinkertaisempia kuin muut ihmiskielet. Pidginien osalta kysymys ei ole kovinkaan kiistanalainen, koska ne eivät ole kenenkään äidinkieliä ja niiden käyttöala on rajattu, joten niiden rakenteellinen yksinkertaisuus on odotuksenmukaista. Mutta kun McWhorter (200I) esitti, että kreolikielten kieliopit ovat yksinkertaisempia kuin muitten äidinkielinä puhuttujen kielten, monet kielentutkijat olivat jyrkästi eri mieltä (jo samaan Linguistic Typology -lehden numeroon oli kerätty monia kommenttipuheenvuoroja). Vastaväitteiden takana oli selvästikin pelko, että yhteiskunnalliselta arvostukseltaan alhaisten kreolikielten nimittäminen yksinkertaisiksi estäisi niiden emansipaatiota ja olisi jopa rasistista.

McWhorterin teos (20II) kielten yksinkertaisuudesta ja monimutkaisuudesta perustelee hänen argumenttejaan laajemmin. Hänen perusteesinsä, jonka mukaan kielten kompleksisuuserot riippuvat merkittävästi siitä, mikä rooli toisen kielen oppimisella ja siis L2-puhujilla on ollut niiden historiassa, on sovellettavissa muihinkin kieliin kuin kreoleihin, vaikka kreolit ovat tietysti tässä mielessä selvin tapaus. Kustersin (2003) uraauurtava väitöskirja osoitti, kuinka arabian, skandinaavisten kielten, ketšuan ja suahilin tiettyjen varieteettien verbintaivutus yksinkertaistui niiden levitessä nopeasti laajoille alueille ja saadessa paljon L2-puhujia. Tällaiset tutkimukset kumosivat oikeastaan kaksikin strukturalistisen lingvistiikan aksioomaa: paitsi sen, että kaikki kielet ovat yhtä monimutkaisia, myös sen, ettei kielen rakenne riipu yhteiskunnallisesta ympäristöstä. Kielten leviäminen ja niistä johtuvat kielikontaktit ja L2-puhujien lisääntyminen ovat kaikki kielten sosiologiaan liittyviä tapahtumia.

On kuitenkin tärkeää huomata, että kielikontaktien on todettu myös monimutkaistavan kieltä. Nichols (1992, 192-195) huomauttaa, että monilla maapallon alueilla, joissa kielellinen diversiteetti on korkea ja puhujat ovat usein monikielisiä, kielet ovat rakenteeltaan hyvin monimutkaisia. Esimerkkejä ovat Kaukasus, luoteinen Pohjois-Amerikka ja 
Uusi-Guinea (vrt. Trudgill 20II, 29-32). Tällaisilla alueilla on paljon kielikontakteja, mutta mikään kieli ei ole levinnyt laajemman alueen lingua francaksi.

Trudgill (20II, 40-43) pyrkii selittämään, miksi kielikontaktit näyttävät toisinaan yksinkertaistavan, toisinaan monimutkaistavan kontaktitilanteisiin osallistuvia kieliä. Verrattain pinnallinen kontakti, johon liittyy ensi sijassa vain sanaston lainaamista, ei todennäköisesti muuta siihen osallistuvien kielten tyyppiä ollenkaan. Laajamittaisempi kontakti sen sijaan johtaa erilaisiin typologisiin muutoksiin sen mukaan, millaiseen yksilötason kaksikielisyyteen se perustuu. Samalla alueella puhuttavien kielten välinen pitkäaikainen kontakti, jossa lapsetkin ovat sujuvasti kaksi- tai monikielisiä, johtaa kielten monimutkaisuuden kasvuun, kun puhujat lisäävät kieliin toisista kielistä lainattuja piirteitä. Sen sijaan kontaktitilanne, jossa aikuiset joutuvat nopeasti opettelemaan heille oudon kielen, johtaa tämän kielen vähittäiseen yksinkertaistumiseen, jos L2-puhujia on kielen puheyhteisössä paljon tai jos heillä on korkea prestiisi (jos he ovat esimerkiksi vierasperäinen eliitti).

Balkanin kieliliittoa tutkinut Lindstedt (20I9) on lisännyt tähän vielä kolmannen tyypin: Balkanin kielten pitkäaikainen kontakti keskiajan lopulla ja uuden ajan ensimmäisinä vuosisatoina perustui ennen kaikkea aikuisten stabiiliin pitkäaikaiseen monikielisyyteen. Sen tuloksia Balkanin kielissä ei voi pitää yksiselitteisesti yksinkertaistavina tai monimutkaistavina, vaan tuloksena oli ennen kaikkea kieliopillisten piirteitten eksplisiittinen merkintä analyyttisesti eli erilaisilla partikkeleilla, artikkeleilla ja prepositioilla. Kielet lainasivat toisiltaan uusia kieliopillisia piirteitä, esimerkiksi evidentiaalisuuden tai määräisyyden pakollisen merkinnän, mikä lisäsi kompleksisuutta sekä sääntöjen että redundanssin muodossa, mutta niiden merkinnässä lisääntyi läpinäkyvyys, mikä puolestaan oli yksinkertaistava muutos.

Kielikontaktien kielioppia yksinkertaistava vaikutus on ollut yksi selitysmalli monen eurooppalaisen kielen historian tutkimuksessa. Useimmat romaaniset kielet ovat kokonaan kadottaneet latinan sijataivutuksen, mikä voidaan selittää sillä, että latina levisi läntiseen ja eteläiseen Eurooppaan ensi sijassa kielenvaihdon kautta ja oli siis aikoinaan suurelle osalle puhujistaan toinen kieli (Clackson \& Horrocks 2007, 276). Latinan 
sijamuodot ovat osittain säilyneet romaniassa ja sen Balkanilla puhuttavissa lähisukukielissä, mikä taas voidaan selittää Balkanin muitten kielten sijajärjestelmän niille antamalla tuella verrattain stabiilissa kielikontaktitilanteessa, jossa ei tapahtunut pelkästään yksisuuntaista laajamittaista kielenvaihtoa (Lindstedt 20I4, I72-I75; Wahlström 20I5, I30-I3I).

Englannin kielen historia on hyvä esimerkki siitä, että kontaktien vaikutusta kieliopin yksinkertaistumiseen ei ole helppo tutkia. Britanniassa puhuttiin kelttiläisiä kieliä englannin puhujien saapuessa 400-500-luvuilla. Sen jälkeen englantiin ovat vaikuttaneet ainakin viikinkien muinaisskandinaavi 70o-luvulta lähtien, maan valloittaneiden normannien ranskan kieli vuodesta Io66 lähtien sekä vielä myöhempien maahanmuuttajien hollanti ja alasaksa (Thomason \& Kaufman I988, 265-269, 32I-325; Filppula 20I3). Jo klassisessa kielikontaktiteoksessaan Thomason ja Kaufman (I988, 263-33I) käyvät laajasti läpi todistusaineistoa ja vertaavat englannin kehitystä muitten germaanisten kielten kehitykseen. Heidän johtopäätöksensä on, että englannin kieliopin yksinkertaistumista kantagermaanista lähtien ei voi pitää tuloksena kontaktista muinaisskandinaavin, ranskan tai myöhempien kontaktikielten kanssa vaan normaalina sisäsyntyisenä kehityksenä. McWhorter (2002) argumentoi kuitenkin, että nimenomaan skandinaavinen kontakti muutti voimakkaasti englannin kielioppia. Viime aikoina on puolestaan esitetty argumentteja sen puolesta, että englantia yksinkertaistikin varhaisempi kelttiläisten kielten ja englannin välinen kontakti ja kielenvaihto, joka jatkui Pohjois-Englannissa pitempään kuin aikaisemmin on ajateltu (Trudgill 20II, 50-55; Filppula 20I3). McWhorter (2OII, 26I-295) on hänkin tarkastellut kelttiläistä vaikutusta, jota hän pitää varmana, vaikkei se hänen mukaansa ole ollut niin yksiselitteisesti kieltä yksinkertaistavaa kuin skandinaavinen vaikutus; hänen mukaansa englanti on semikreoli (ks. luku 3.5.).

Kielikontaktien typologinen vaikutus on siis ollut kiistanalaista jopa englannissa, jota on tutkittu paljon ja jonka sisäinen ja ulkoinen historia tunnetaan hyvin. Metodologinen opetus tästä on, että mitä laajemmista kieliopillisista muutoksista on kyse, sitä epävarmemmiksi kontaktipohjaiset selitykset käyvät, vaikkei olekaan mitään periaatteellista syytä, miksi kontaktiselitykset olisivat huonompia kuin kielen sisäisiin syihin 
vetoavat selitykset. Luonnollisesti yhtä kieltä tutkittaessa ei voida olla oikopäätä varmoja siitä, mikä lopulta on ollut kielikontaktien ja kielen sisäisten, esimerkiksi sananloppuisten fonologisten muutosten keskinäinen osuus, mutta kun tietynlaisten sosiolingvististen kontaktitilanteiden osoitetaan johtavan eri kielissä säännöllisesti samanlaisiin muutoksiin (esimerkkinä edellä siteerattu Kusters 2003), kontaktiselityksen paino jokaisessa yksittäistapauksessakin kasvaa. Selitys voi olla myös sisäisten syiden ja useamman kuin yhden kontaktitilanteen yhteisvaikutus, kuten Wahlström (20I5) on osoittanut tutkimuksessaan sijataivutuksen kadosta bulgariassa ja makedoniassa.

\section{Yhteenveto: mitä kielikontaktien tutkijalta vaaditaan}

Kuten tässä artikkelissa on käynyt ilmi, kielikontaktien tutkimus voi koskea mitä tahansa kielen tasoa, mikä johtuu puolestaan siitä, että kontaktilähtöinen kielenmuutos voi tapahtua millä tahansa kielen tasolla ääntämyksestä semantiikkaan ja pragmatiikkaan. Kielikontaktien tutkijan tulee näin ollen tuntea sitä kielitieteen alaa, joka hänen tarkastelemiaan ilmiöitä tutkii. Laajasti käytettyjä, helposti sovellettavia malleja ei kielikontaktien tutkimuksessa juurikaan ole, ja kontaktien tutkijan tarvitsemaa metodologista osaamista ei ole aivan yksinkertaista määritellä.

Sarah Thomason (20I0) kuvaa artikkelissaan sitä, millaisen tutkimusprosessin kautta jonkin ilmiön kontaktilähtöisyys voidaan osoittaa. Prosessi ilmentää hyvin niitä erilaisia metodologisia valmiuksia, jotka voivat olla kontaktien tutkijalle tarpeen. Tutkittavia kieliä tulee tuntea kokonaisuutena, jotta voisi todeta, onko kielessä muita lainautuneita rakenteita. On myös kyettävä tarvittaessa osoittamaan, että ilmiön synnyn aikaan on vallinnut lainautumiselle otollinen sosiolingvistinen tilanne. On toisin sanoen tunnettava tutkittavan kielen kehityshistoriaa ja mahdollisesti myös puhujayhteisön kielenulkoista historiaa, tai jos kyse on tuoreesta ilmiöstä, sen nykyistä tilannetta. 
Jotta taas kykenisi määrittelemään, mikä lainattua rakennetta lähtö- ja kohdekielessä yhdistää, on pystyttävä käyttämään laajemmin yleistettävissä olevia vertailukäsitteitä, jotka eivät nojaa pelkästään yhden kielen kuvaus- ja tutkimustraditioon. Tällaista otetta vaaditaan myös kontrastiivisessa kielentutkimuksessa, jossa kieliä vertaillaan myös ilman oletusta niiden välisestä kontaktivaikutuksesta (ks. kielten vertailun metodiikasta Kolehmainen, Miestamo \& Nordlund 20I3). Osoittaakseen, että kontaktiilmiö todella on uusi kohdekielessä - tai vanha lähtökielessä -, tulee tutkijan verrata tutkittavia kieliä niiden sukukieliin tai varhaisempiin kielimuotoihin. Tällöin kyseeseen tulevat esimerkiksi historiallis-vertailevan kielentutkimuksen menetelmät, tai jos epäilty kontaktimuutos on nähtävissä kirjallisessa aineistossa, myös historiallinen korpustutkimus voi olla tarpeen (ks. Historiallinen korpuslingvistiikka tk.).

Edellä kuvatut menetelmälliset valmiudet eivät koske pelkästään kontaktitutkimusta. Usein kielikontaktien tutkijan erikoisosaaminen on tutkittavien kielten, niiden puhujayhteisöiden ja erityyppisten kielikontaktitilanteiden tuntemusta. Ei riitä pelkästään, että tuntee kielen, jossa tapahtuvia ilmiöitä havainnoi, vaan myös muutoksen lähteenä olevaa kieltä on syytä tuntea. Jos tarkastellaan synkronisia ilmiöitä ja käytetään esimerkiksi keskusteluaineistoa, korostuu tutkijan kielitaidon merkitys entisestään. Jos taas kyse on diakronisesta tutkimuksesta, on tunnettava myös niitä kielen varieteetteja, joihin otaksuttu kontakti ei ole vaikuttanut ja joiden voi näin ollen olettaa edustavan paremmin kontaktia edeltänyttä tilannetta. Toisaalta kun aineistona on typologinen piirreotos kuten makroalueiden tutkimuksessa, ei yksittäiskielten osaaminen ole välttämätöntä. Tällöin tarvitaan kuitenkin ymmärrystä kielityypeistä ja siitä, millaisin vertailukäsittein yksittäiskielten ilmiöt voidaan rinnastaa toisiinsa (ks. Kielitypologian menetelmät tk.).

Tässä artikkelissa on osoitettu, että kielikontakti-ilmiöiden selittäminen kietoutuu aina puhujayhteisöissä vallitsevien sosiolingvististen asetelmien ymmärtämiseen. Usein on yhtä tärkeää havainnoida kielenkäyttötilanteita kuin niitä kielen rakenteita, joissa ilmiö esiintyy. Joskus kontakti-ilmiön todistaminen jopa vaatii, että pystyy osoittamaan kontaktitilanteen olleen sen kaltaisen, että lainautuminen on ylipäätään ollut mahdollista. Myös monikielisten käytänteiden tarkastelu sinänsä 
on osa kielikontaktitutkimusta laajassa mielessä. Kontaktiin johtaneen tilanteen ymmärtämisessä mikään ei voita sitä kokemusta, joka saavutetaan oleskelemalla tutkittavan puhujayhteisön parissa - silloinkin kun aineistoa ei hankita kenttätyössä.

Tutkija operoi aina myös intuitiollaan, jossa on kyse tiedon ja kokemuksen yhdistelmästä. Tuottaakseen tutkittavia hypoteeseja kontaktitutkijan tulee tuntea kontakti-ilmiöitä yleensä: mikä on mahdollista ja millaisissa olosuhteissa sekä millaisia syy-seuraus- ja muita riippuvuussuhteita ilmiöiden välillä voidaan havaita. Voidaankin sanoa, että keskeisen osan kontaktitutkijan metodologisesta osaamisesta muodostaa tutkimuskirjallisuuteen perehtyminen laajasti ja ennakkoluulottomasti, ja aloittaa voi esimerkiksi tämän artikkelin kirjallisuusluettelosta.

\section{Aiheesta lisää:}

Hickey, Raymond (toim.). 2010. The Handbook of Language Contact. Chichester, West Sussex \& Malden (MA): Wiley-Blackwell.

Hickey, Raymond (toim.). 2017. The Cambridge Handbook of Areal Linguistics. Cambridge: Cambridge University Press.

Journal of Language Contact. Saatavissa: https://brill.com/view/journals/ jlc/jlc-overview.xml.

Journal of Pidgin and Creole Languages. Saatavissa: https://www.jbe-platform.com/content/journals/15699870.

Nichols, Johanna. 1992. Linguistic Diversity in Space and Time. Chicago and London: The University of Chicago Press.

Thomason, Sarah G. 2001. Language Contact: An Introduction. Washington (DC): Georgetown University Press.

Trudgill, Peter. 2011. Sociolinguistic Typology: Social Determinants of Linguistic Complexity. Oxford: Oxford University Press. 


\section{VIITTEET}

\section{1 https://www.bbc.com/pidgin}

\section{KIRJALLISUUS}

Adamou, Evangelia. 2012. Social networks in Greek Thrace: Language shift and language maintenance. Julkaisussa: Lindstedt, Jouko \& Wahlström, Max (toim.) Balkan Encounters: Old and New Identities in South-Eastern Europe. Slavica Helsingiensia 41. Helsinki: Helsingin yliopisto, 7-32. Saatavissa: https://blogs.helsinki.fi/slavica-helsingiensia/ slavica-helsingiensia-41/.

Anttila, Raimo. 1972. An Introduction to Historical and Comparative Linguistics. New York (NY): Macmillan.

Arends, Jacques, Muysken, Pieter \& Smith, Norval (toim.). 1995. Pidgins and Creoles: An Introduction. Creole Language Library 15. Amsterdam: John Benjamins.

Auwera, Johan van der. 1998. Conclusion. Julkaisussa: Auwera, Johan van der (toim.) Adverbial Constructions in the Languages of Europe. Empirical Approaches to Language Typology, EUROTYP 20-3. Berlin: Mouton de Gruyter, 813-836.

Bartens, Angela. 2009. Kreolikielistä. Julkaisussa: Kalliokoski, Jyrki, Kotilainen, Lari \& Pahta, Päivi (toim.) Kielet kohtaavat. Tietolipas 227. Helsinki: Suomalaisen Kirjallisuuden Seura, 50-74.

Bloomfield, Leonard. 1933. Language. New York (NY): Henry Holt.

Boas, Franz. 1911. Handbook of American Indian Languages, osa 1. Washington: Smithsonian Institution, Bureau of American Ethnology.

Boduen-de-Kurtenè, Ivan A. 1901. O směšannom harakterě vsěh jazykov. Žurnal Ministerstva narodnago prosvěščenija 337, 12-24.

Broch, Ingvild \& Jahr, Ernst Håkon. 1984. Russenorsk: et pidginspråk i Norge. (2. laitos.) Oslo: Novus.

Campbell, Lyle. 2006. Areal linguistics: A closer scrutiny. Julkaisussa: Matras, Yaron, MacMahon, April \& Vincent, Nigel (toim.) Linguistic Areas: Convergence in Historical and Typological Perspective. New York (NY): Palgrave Macmillan, 1-31.

Clackson, James \& Horrocks, Geoffrey. 2007. The Blackwell History of the Latin Language. Malden (MA): Blackwell.

Contact Language Library. John Benjamins. (Aiempi nimi: Creole Language Library.)

Dahl, Östen. 2004. The Growth and Maintenance of Linguistic Complexity. Studies in Language Companion Series 71. Amsterdam: John Benjamins.

Dahl, Östen. 2008. Kuinka eksoottinen kieli suomi on. Virittäjä 112:4, 545-559.

Darwin, Charles. [1874]. The Descent of Man and Selection in Relation to Sex. (2. laitos). [verkkoaineisto]. [viitattu 29.3.2018.] Saatavissa: http://www.gutenberg.org/ebooks/2300. Dryer, Matthew S. 1989. Large linguistic areas and language sampling. Studies in Language 13:2, 257-292.

Edwards, John R. 1994. Multilingualism. London: Routledge. 
Emeneau, Murray Barnson. 1956. India as a Lingustic Area. Language 32:1, 3-16.

Enfield, Nick J. 2005. Areal linguistics and mainland Southeast Asia. Annual Review of Anthropology 34, 181-206.

EUROTYP = Eurotyp 1 - Eurotyp 8 = Empirical Approaches to Language Typology 20-1 - 20-8. Mouton de Gruyter 1997-2011.

Feuillet, Jack. 2012. Linguistique comparée des langues balkaniques. Collection de manuels publiée par l'Institute d'études slaves. Paris: Institute d'études slaves.

Filppula, Markku. 2013. Contact and the early history of English. Julkaisussa: Hickey, Raymond (toim.) The Handbook of Language Contact. Chichester: Wiley-Blackwell, 432453.

Fishman, Joshua A. 1964. Language maintenance and language shift as a field of inquiry: A definition of the field and suggestions for its further development. Linguistics 2:9, 32-70.

Haan, Ferdinand de. 2013. Semantic distinctions of evidentiality. Julkaisussa: Dryer, Matthew S. \& Haspelmath, Martin (toim.) The World Atlas of Language Structures Online. [verkkoaineisto]. [viitattu: 4.12.2017]. Leipzig: Max Planck Institute for Evolutionary Anthropology. Saatavissa: https://wals.info/chapter/77.

Haarmann, Harald. 1970. Die indirekte Erlebnisform als grammatische Kategorie. Eine eurasische Isoglosse. Veröffentlichungen der Societas Uralo-Altaica, 2. Wiesbaden: Otto Harrassowitz.

Hakulinen, Lauri. 1968. Suomen kielen rakenne ja kehitys. (3. p.). Helsinki: Otava.

Hall, Robert A. 1946. Bartoli's 'neolinguistica'. Language 22:4, 273-283.

Haspelmath, Martin. 1998. How young is Standard Average European? Language Sciences 20:3, 271-287.

Haspelmath, Martin. 2001. The European linguistic area: Standard Average European. Julkaisussa: Haspelmath, Martin, König, Ekkehard, Oesterreicher, Wulf \& Raible, Wolfgang (toim.) Language Typology and Language Universals - Sprachtypologie und sprachliche Universalien - La typologie des langes et les universaux linguistiques. Handbücher zur Sprach- und Kommunikationwissenschaft 20. Berlin: de Gruyter, 1492-1510.

Haspelmath, Martin \& Tadmor, Uri (toim.). 2009. Loanwords in the World's Languages: A Comparative Handbook. Berlin: De Gruyter Mouton.

Heine, Bernd \& Kuteva, Tania. 2006. The Changing Languages of Europe. Oxford: Oxford University Press.

Häkkinen, Kaisa. 1990. Mistä sanat tulevat: Suomalaista etymologiaa. Helsinki: Suomalaisen Kirjallisuuden Seura.

Joseph, Brian D. 2010. Language contact in the Balkans. Julkaisussa: Hickey, Raymond (toim.) The Handbook of Language Contact. Malden (MA): Wiley-Blackwell, 618-633. Journal of Language Contact. Saatavissa: https://brill.com/view/journals/ilc/ilc-overview.xml. Journal of Pidgin and Creole Languages. Saatavissa: https://www.jbe-platform.com/content/ journals/15699870.

Kallio, Petri. 2006a. On the earliest Slavic loanwords in Finnic. Julkaisussa: Nuorluoto, Juhani (toim.) The Slavicization of the Russian North: Mechanisms and Chronology. Slavica Helsingiensia 27. Helsinki: Helsingin yliopisto, 154-166.

Kallio, Petri. 2006b. Suomen kantakielen absoluuttista kronologiaa. Virittäjä 110:1, 2-25. Kallio, Petri. 2007. How Uralic is Stadin Slangi? Julkaisussa: Blokland, Rogier \& Hasselblatt, 
Cornelius (toim.) Language and Identity in the Finno-Ugric World. Studia Fenno-Ugrica Groningana 4. Maastricht: Shaker Publishing, 176-191.

Kolehmainen, Leena, Miestamo, Matti \& Nordlund, Taru (toim.). 2013. Kielten vertailun metodiikka. Helsinki: Suomalaisen Kirjallisuuden Seura.

Kopitar, Jernej. 1829. Albanische, walakische u. bulgarische Sprache. Jahrbücher der Literatur (Wien) 46, 59-106.

Kouwenberg, Silvia \& Singler, John Victor (toim.). 2008. The Handbook of Pidgin and Creole Studies. Chichester: Wiley-Blackwell.

Kuronen, Mikko \& Leinonen, Kari. 2001. Fonetiska skillnader mellan finlandssvenska och rikssvenska. Julkaisussa: Jönsson, Linda, Adelswärd, Viveca, Cederberg, Ann, Pettersson, Per A. \& Kelly, Caroline (toim.) Svenskans beskrivning 24. Förhandlingar vid tjugofjärde sammankomsten för svenskans beskrivning, Linköping den 22-23 oktober 1999. Linköping: Linköping University Electronic Press, 125-138.

Kusters, Wouter. 2003. Linguistic Complexity: the Influence of Social Change on Verbal Inflection. Utrecht: LOT. [verkkoaineisto]. [viitattu 29.3.2018.] Saatavissa: http://www. lotpublications.nl/Documents/077_fulltext.pdf.

Lehtonen, Heini. 2015. Typlitellen: Nuorten kielelliset resurssit ja kielen sosiaalinen indeksisyys monietnisessä Helsingissä. Väitöskirja. Helsinki: Helsingin yliopisto. Saatavissa: http://urn. fi/URN:ISBN:978-957-51-1333-7.

Lindstedt, Jouko. 2000. The perfect - aspectual, temporal and evidential. Julkaisussa: Östen Dahl (toim.) Tense and Aspect in the Languages of Europe. Empirical Approaches to Language Typology, Eurotyp 20-6. Berlin: Mouton de Gruyter, 365-383.

Lindstedt, Jouko. 2004. Imaginary roots. Finnisch-Ugrische Forschungen 58:1-3, 307-313.

Lindstedt, Jouko. 2009a. Balkanin kieliliitto. Julkaisussa: Kalliokoski, Jyrki, Kotilainen, Lari \& Pahta, Päivi. 2009 (toim.) Kielet kohtaavat. Tietolipas 227. Helsinki: Suomalaisen Kirjallisuuden Seura, 75-95.

Lindstedt, Jouko. 2009b. Esperanto - an East European contact language? Julkaisussa: Voß, Christian \& Nagórko, Alicja (toim.) Die Europäizität der Slawia oder die Slawizität Europas: Ein Beitrag der kultur- und sprachrelativistischen Linguistik. Studies on Language and Culture in Central and Eastern Europe 2. München: Otto Sagner, 125-134.

Lindstedt, Jouko. 2014. Balkan Slavic and Balkan Romance: from congruence to convergence. Julkaisussa: Besters-Dilger, Juliane, Dermarkar, Cynthia, Pfänder, Stefan \& Rabus, Achim (toim.) Congruence in Contact-Induced Language Change. Berlin: De Gruyter, 168-183.

Lindstedt, Jouko. 2019. Diachronic regularities explaining the tendency towards explicit analytic marking in Balkan syntax. Julkaisussa: Krapova, Iliyana \& Joseph, Brian (toim.) Balkan Syntax and (Universal) Principles of Grammar. Trends in Linguistics, Studies and Monographs 285. Berlin: De Gruyter Mouton, 70-84.

Matras, Yaron. 2002. Romani: A Linguistic Introduction. Cambridge: Cambridge University Press.

McWhorter, John H. 2001. The world's simplest grammars are creole grammars. Linguistic Typology 5:2-3, 125-166.

McWhorter, John. 2002. What happened to English? Diachronica 19, 217-272.

McWhorter, John H. 2011. Linguistic Simplicity and Complexity: Why Do Languages Undress? 
Language Contact and Bilingualism 1. Boston: De Gruyter Mouton.

McWhorter, John H. 2018. The Creole Debate. Cambridge: Cambridge University Press.

Meijer, Guus \& Muysken, Pieter. 1977. On the beginnings of pidgin and creole studies: Schuchardt and Hesseling. Julkaisussa: Valdmann, Albert (toim.) Pidgin and Creole Linguistics. Bloomington: Indiana University Press, 21-45.

Miestamo, Matti. 2008. Grammatical complexity in cross-linguistic perspective. Julkaisussa: Miestamo, Matti, Sinnemäki, Kaius \& Karlsson, Fred (toim.) Language Complexity: Typology, Contact, Change. Studies in Language Companion Series 94. Amsterdam: John Benjamins, 23-41.

Miestamo, Matti. 2017. Linguistic diversity and complexity. Lingue e linguaggio 16:2, 227253.

Mufwene, Salikoko S. 2008. Language Evolution: Contact, Competition and Change. London: Continuum.

Muysken, Pieter. 2000. Bilingual Speech: A Typology of Code-Mixing. Cambridge: Cambridge University Press.

Muysken, Pieter. 2013. Language contact outcomes as the result of bilingual optimization strategies. Bilingualism: Language and Cognition 16:4, 709-730.

Myers-Scotton, Carol. 2002. Contact Linguistics: Bilingual Encounters and Grammatical Outcomes. Oxford: Oxford University Press.

Nichols, Johanna. 1992. Linguistic Diversity in Space and Time. Chicago (IL): The University of Chicago Press.

Nicolaï, Robert. 2014. À propos de Schuchardt, du mélange des langues et du contact. Journal of Language Contact 7:2, 211-249.

Palosaari, Naomi \& Campbell, Lyle. 2011. Structural aspects of language endangerment. Julkaisussa: Austin, Peter K. \& Sallabank, Julia (toim.) The Cambridge Handbook of Endangered Languages. Cambridge: Cambridge University Press, 100-119

Pellegrini, Giovanni Battista. 1980. Substrata. Julkaisussa: Posner, Rebecca \& Green, John (toim.) Romance Comparative and Historical Linguistics. Berlin: De Gruyter, 43-73.

Schmid, Monika S. 2011. Language Attrition. Cambridge: Cambridge University Press.

Steinmetz, Katy. 2014. The absolute final, last word of the year: Because. Because grammar.

Time 8.1.2014. [verkkoaineisto]. [viitattu 4.12.2017.] Saatavissa: https://newsfeed.time. $\mathrm{com} / 2014 / 01 / 08 /$ the-absolute-final-last-word-of-the-year-because/.

Thomason, Sarah G. 2001. Language Contact: An Introduction. Washington (DC):

Georgetown University Press.

Thomason, Sarah G. 2010. Contact explanations in linguistics. Julkaisussa: Hickey, Raymond (toim.) The Handbook of Language Contact. Malden (MA): Wiley-Blackwell, 31-47.

Thomason, Sarah Grey \& Kaufman, Terrence. 1988. Language Contact, Creolization, and Genetic Linguistics. Berkeley: University of California Press.

Trubetzkoy, Nikolai S. 1923. Vavilonskaja bašnja I smešenie jazykov. Evrazijskij vremennik 3, 107-124.

Trubetzkoy, Nikolai S. 1928. [proposition 16]. Julkaisussa: Actes du premier Congrès international de linguistes, 17-18.

Trudgill, Peter. 1986. Dialects in Contact. Oxford: Blackwell. 
Trudgill, Peter. 2011. Sociolinguistic Typology: Social Determinants of Linguistic Complexity. Oxford: Oxford University Press.

Wahlström, Max. 2015. The Loss of Case Inflection in Bulgarian and Macedonian. Slavica Helsingiensia 47. Helsinki: University of Helsinki. Saatavissa: https://blogs.helsinki.fi/ slavica-helsingiensia/slavica-helsingiensia-47/.

WALS = Dryer, Matthew S. \& Haspelmath, Martin (toim.) The World Atlas of Language Structures Online. Leipzig: Max Planck Institute for Evolutionary Anthropology. [verkkoaineisto]. [viitattu 29.3.2018.] Saatavissa: https://wals.info.

Weinreich, Uriel. 1970 [1953]. Languages in Contact: Findings and Problems. The Hague: Mouton.

Whorf, Benjamin. 2012. Language, Thought, and Reality: Selected Writings of Benjamin Lee Whorf. Toim. John B. Carroll, Stephen C. Levinson \& Penny Lee. Cambridge (MA): MIT Press.

Wiik, Kalevi. 2002. Eurooppalaisten juuret. Jyväskylä: Atena Kustannus. 